\title{
COVID-19 döneminde algılanan tehdit, kayg1 ve dürtüsel satın alma ilişkisinde algılanan duyarlılığın ve ciddiyetin moderatör rolü
}

\section{The moderator role of perceived susceptibility and severity in relationship perceived threat, anxiety, and impulsive buying in COVID-19 period}

\author{
Mehmet Sağlam ${ }^{1}$ \\ E. Başak Tavman ${ }^{2}$
}

${ }^{1}$ Dr. Öğr. Üyesi, İstanbul Ticaret

Üniversitesi, İstanbul, Türkiye, msaglam@ticaret.edu.tr

ORCID: 0000-0002-1909-4284

2 Arş. Gör, Işık Üniversitesi, İstanbul, Türkiye, basak.tavman@isikun.edu.tr

ORCID: 0000-0002-2544-9467

Sorumlu Yazar/Corresponding Author: Mehmet Sağlam,

İstanbul Ticaret Üniversitesi, İstanbul, Türkiye, msaglam@ticaret.edu.tr

Başvuru/Submitted: 22/04/2021

Revizyon/Revised: 27/05/2021

Kabul/Accepted: 2/06/2021

Yayın/Online Published: 25/06/2021

Atıf/Citation: Sağlam, M., \& Tavman, E.B. COVID-19 döneminde algilanan tehdit, kayg1 ve dürtüsel satın alma ilişkisinde algilanan duyarlılığın ve ciddiyetin moderatör rolü, bmij (2021) 9 (2): 673-693, doi:

https://doi.org/10.15295/bmij.v9i2.1819
Öz

Tüm dünyanın gündemine oturan küresel COVID-19 salgını milyarlarca insan arasında korku, panik ve belirsizliği tetikleyerek tüketicilerin dürtüsel satın alma davranışı sergilemesine neden olmuştur. $\mathrm{Bu}$ davranışın öncüllerinin ve düzenleyicilerinin neler olduğu ise merak konusudur. Bu çalışmada, Türkiye'deki COVID-19 salgını bağlamında uyarıcı-organizma-tepki (S-O-R) Paradigması ve Sağlık İnanç Modeli çerçevesinde, algılanan tehdidin (uyarıcı) kaygı (organizma) üzerindeki etkileri ve kaygının dürtüsel satın alma davranışı (tepki) üzerindeki etkileri incelenmeye çalışılmıştır. Ek olarak, algılanan duyarlılık ve algılanan ciddiyet değişkenlerinin bu ilişkiler üzerindeki düzenleyici etkileri araştırılmıştır. Çalışmada kolayda örnekleme ve kartopu örnekleme yöntemi kullanılmış ve veriler Google Forms üzerinden online anket aracılığıyla toplanmıştır. Çalışma 403 katılımcı üzerinde gerçekleştirilmiştir. Elde edilen verilerin analizinde SPSS 24 ve AMOS 24 programları kullanılmıştır. Araştırma sonucunda, algılanan tehdidin kaygı üzerinde etkisi olduğu ve algilanan duyarlılık ve ciddiyetin bu ilişkide düzenleyici role sahip olduğu, ayrıca kaygının dürtüsel satın alma üzerinde etkisi olduğu ve yine algılanan duyarlılık ve ciddiyetin bu ilişkide düzenleyici role sahip olduğu sonucuna ulaşılmıştır.

Anahtar Kelimeler: COVID-19, Algılanan Tehdit, Kaygı, Dürtüsel Satın Alma, Algilanan Duyarlılık, Algilanan Ciddiyet

Jel Kodları: M30, M31

\begin{abstract}
The global COVID-19 epidemic, which is on the agenda of the whole world, has caused impulsive buying behaviour by triggering fear, panic and uncertainty among billions of people. However, what is the antecedents and moderators of this behaviour is a matter of curiosity. This study has been studied that on the COVID-19 epidemic process in Turkey, the effect of perceived threat (stimuli) on anxiety (organism) and its effects on impulsive buying (response) as based on the framework of the stimulus-organism-response (SOR) paradigm and the Health Belief Model. Additionally, the moderator effects of perceived susceptibility and severity variables on these relationships were investigated. In the study, convenience and snowball sampling methods were used, and the data were collected via an online questionnaire on Google Forms. The study was carried out on 403 participants. SPSS 24 and AMOS 24 programs were used in data analysis. As a result of the study, it was concluded that the perceived threat affected anxiety and that perceived susceptibility and severity had a moderator role in this relationship, and that anxiety had an effect on impulsive buying. Furthermore, that perceived susceptibility and severity had a moderator role in this relationship.
\end{abstract}

Keywords: COVID-19, Perceived Threat, Anxiety, Impulsive Buying, Perceived Susceptibility, Perceived Severity

Jel Codes: M30, M31 


\section{Extended Abstract}

The moderator role of perceived susceptibility and severity in relationship perceived threat, anxiety, and impulsive buying in COVID-19 period

\section{Literature}

\section{Research Subject}

The global COVID-19 outbreak has triggered fear, panic and uncertainty among billions of people. COVID-19, which caused necessary changes in many aspects such as business manners, economy, daily life and social needs, also changed the habits of consumers for many years. The loss of clarity of purchasing behaviour in times of uncertainty has created visible changes in consumer behaviour. As a result of the COVID-19 outbreak, social distancing and lockdown obligations have completely changed consumers' purchasing and shopping habits, as well as their consumption habits (Donthu \& Gustafsson, 2020; Sheth, 2020). Impulsive buying has become a global phenomenon reflecting the loss of control among consumers during the pandemic. In response to the COVID-19 threat, many people are concerned about contracting the disease. Fear of illness, fear of product shortages, fear of price increases, and social tendency to overbuy have increased impulsive buying behaviour among consumers (Naeem, 2021; Slickdeals, 2020; Xiao, Zhang, \& Zhang, 2020). In addition, increasing anxiety to meet unlimited needs with limited resources has caused an increase in impulsive buying by causing anxiety in consumers (Ipsos, 2020).

\section{Research Purpose and Importance}

In this study, the model created under the S-O-R Paradigm and Health Belief Model aimed to examine the moderator effects of perceived severity and perceived susceptibility to perceived threat and anxiety within the scope of COVID-19 on impulsive buying of consumers. Based on the premises about risk perception, two sub-dimensions of perceived health threat from the Health Belief Model, perceived severity and perceived susceptibility, were included in the model as moderator variables. The S-O-R paradigm is a model evaluated within the framework of environmental psychology, which suggests that environmental stimuli and emotions affect the behaviour of individuals (Mehrabian \& Russell, 1974). The model examined as Stimulus, Organism and Response is based on many studies examining consumer behaviour. The Health Belief Model claims that individuals' health behaviours will be affected by their beliefs, values and attitudes. The model is the most preferred model used to reveal the factors affecting health behaviours (Rohleder 2012). The limited number of theoretical studies on the psychological effects of the COVID19 pandemic in the studies conducted in this context reveals the importance of the research. The proposed model, integrating the S-O-R paradigm and the Health Belief Model, assumes that perceived threat and anxiety affect impulsive buying, and perceived severity and perceived susceptibility have moderator effects on them. This study aims to determine the moderator role of perceived susceptibility and perceived severity in perceived threat, anxiety and impulsive buying relationship during the COVID19.

\section{Contribution of the Article to the Literature}

There are limited numbers of studies on why and how psychological situations that emerge in the uncertain and panic conditions of the COVID-19 pandemic change rational and economic purchasing decisions. The study's findings are expected to fill the literature gap and guide businesses to understand changing consumer behaviours and formulate their strategies in times of panic.

\section{Design and Method}

This research is designed as quantitative research. Research model and hypotheses have been developed within the scope of the information obtained from the literature. SPSS 24 and AMOS 24 programs were used in data analysis. Structural equation modelling was used to examine the hypothesis tests.

\section{Research Type}

The type of research is the relational research model, and it is a quantitative study.

\section{Data Collection Method}

An online questionnaire gathered the data included in the study. Convenience and snowball sampling methods were used, and data were collected from 403 participants. The items were rated on five-point Likert scales, ranging from 1 (strongly disagree) to 5 (strongly agree). Perceived severity and susceptibility scale were measured three items for every scale based on Farooq et al. (2020) and Ling et al. (2019). The anxiety scale was measured five items based on Marteau and Bekker (1992), the measures for the perceived threat was based on Yang (2012) and Lin and Bautista (2016). Finally, the impulsive buying scale was taken from Verhagen and van Dolen (2011).

\section{Quantitative Analysis}

In the research analysis, SPSS 24 program was used for descriptive statistics, reliability test and correlation analysis, while the AMOS 24 package program was used for confirmatory factor analysis, validity analysis and structural equality path analysis.

\section{Research Hypotheses}

The hypotheses of the research are as follows:

H1: Perceived threat affects anxiety in the COVID-19 period.

H2: Anxiety affects impulsive buying in the COVID-19 period

H3: Perceived susceptibility has a moderator effect on perceived threat and anxiety in the COVID-19 period.

H4: Perceived susceptibility has a moderator effect on the effect of anxiety on impulsive buying in the COVID-19 period.

H5: Perceived severity has a moderator effect on perceived threat and anxiety in the COVID-19 period.

H6: Perceived severity has a moderator effect on the effect of anxiety on impulsive buying in the COVID-19 period. 


\section{Research Model}

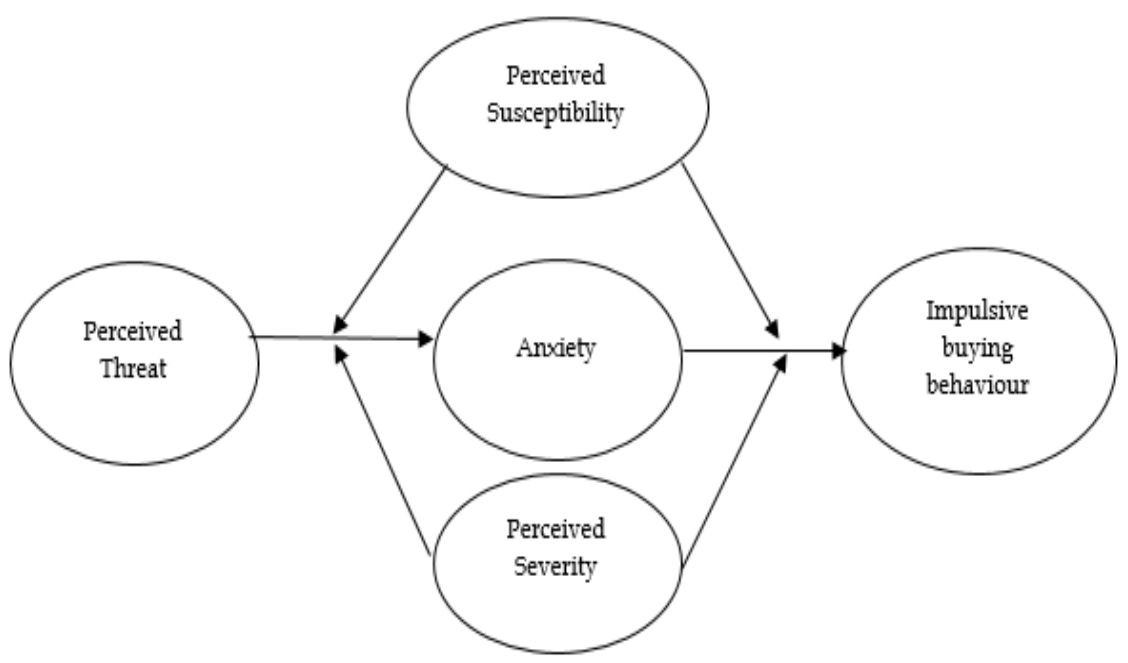

Figure 1. Research Model

\section{Findings and Discussion}

\section{Findings as a Result of Analysis}

The structural equation path analysis results determined that perceived threat had a positive effect on anxiety, and anxiety positively affected impulsive buying. Furthermore, when the moderator effects were examined, it was concluded that perceived susceptibility and perceived severity had a moderator effect on the effect of perceived threat on anxiety and the effect of anxiety on impulsive buying. Thus, the established model is statistically meaningful.

\section{Hypothesis Test Results}

As a result of the research, all proposed hypotheses were accepted.

\section{Discussing the Findings with the Literature}

It is seen that the findings obtained about the research are consistent with the consequences of the previous studies. When the findings obtained from the study are compared with the results of the study in the literature, the effect of perceived threat on anxiety by Song, Yao, and Wen (2021), Shahzad et al. (2020), and Paredes et al. (2021), the effect of anxiety on impulsive buying by Laato et al. (2020), Xiao, Zhang, and Zhang (2020) studies and finally moderator effects are in parallel with Sheeran and Abraham (1996), Joshi and Rahman (2015), Laato et al. (2020) studies.

\section{Conclusion, Recommendation and Limitations}

\section{Results of the Article}

As a result of the research, it was revealed that if the perceived threat of consumers against COVID-19 increases, their anxiety levels will increase, and similarly, if their anxiety levels increase, impulsive buying behaviour will increase. Increasing the perceived susceptibility and severity levels of consumers against COVID-19 will strengthen these effects. It was determined that perceived severity did strengthen the anxiety level on impulsive buying and had a moderator role.

\section{Suggestions Based on Results}

In future studies, the effect of COVID-19 perceived threat, anxiety, susceptibility and severity variables on stockpiling and waste avoidance behaviours can be addressed. In addition, research can be deepened with different research models and data collection methods. Comparative analysis can be done on COVID-19 positive and negative cases. Another research can be conducted on consumers under 20 or over 65 affected by the COVID-19 restrictions.

It is thought that the results of the research will be a guide for marketing managers. Therefore, it can be concluded that managers should evaluate how consumer behaviour will change according to the increase and decrease in the number of cases in the COVID-19 period.

\section{Limitations of the Article}

The study was conducted on people who had a negative COVID-19 test and did not test. This is a limitation of the study. The data obtained from the study were collected between 4 January and 15 January 2021. The results should be interpreted according to the case situation in this date range and not generally. Therefore, findings obtained with a larger sample group can be investigated. In addition, whether the participants who were themselves negative in the sample group had positive people with the COVID-19 test around them was ignored. Even if the person's test is not favourable, the positive test of someone from the family or friends will affect the consumption behaviour of these people. In order to better define these situations in the future, studies can be repeated by considering such questions. 


\section{Giriş}

Küresel COVID-19 salgını, milyarlarca kişi arasında korku, panik ve belirsizliği tetiklemiştir. İş yapış biçimleri, ekonomi, günlük yaşam ve sosyal ihtiyaçlar gibi birçok noktada zorunlu değişikliklere neden olan COVID-19, tüketicilerin uzun yıllardır geliştirdiği alışkanlıklarını da değiştirmiştir. Belirsizlik dönemlerinde satın alma davranışının netliğini yitirmesi tüketici davranışlarında gözle görülür değişimler yaratmıştır. Psikoloji alanındaki çalışmalar, salgın zamanlarında hastalı̆̆ın yayılmasını önlemek için bireylerin davranışlarını değiştirme eğilimleri içerisinde olduklarını kanıtlamışır (Ferguson, 2007; Yuen, Wang, Ma ve Li, 2020).

COVID-19 salgınının bir sonucu olarak, sosyal mesafe ve kapanma zorunlulukları, tüketicilerin satın alma ve alışveriş alışkanlıklarının yanı sıra tüketim alışkanlıklarını da tamamen değiştirmiştir (Donthu ve Gustafsson, 2020; Sheth, 2020). Dürtüsel satın alma, salgın döneminde tüketiciler arasındaki kontrol kaybını yansıtan küresel bir fenomen haline gelmiştir. Shaikh (2020), COVID-19 pandemisinin tüketici davranışında değişime neden olduğunu ve pazarlama stratejilerinin buna göre şekillenmesi gerektiğini savunmaktadır (Shaikh, 2020: 408).

Mart 2021'nin sonunda COVID-19, 188 ülkede 133 milyondan fazla doğrulanmış vaka ve 3milyondan fazla ölümle sonuçlanmıştır (BBC News, 2021). Bu nedenle, hastalık tehdidinin pandemi bağlamındaki birincil çevresel uyaran olduğu düşünülmektedir. COVID-19 tehdidine yanıt olarak, birçok kişi hastalığa yakalanma endişesi duymaktadır. Hastalık korkusu, ürün kıtlığı, fiyat artışı korkusu ve fazladan satın almaya yönelik sosyal eğilim, tüketiciler arasında panik kaynaklı dürtüsel satın alma davranışını artırmıştır (Naeem, 2021; Slickdeals, 2020; Xiao, Zhang ve Zhang, 2020). Sınırlı kaynaklarla sınırsız ihtiyaçları karşılama endişesinin artması tüketicilerde kaygı yaratarak dürtüsel satın almada artışa yol açmıştır (Ipsos, 2020). Tüketicilerin yaklaşık \%71'i, COVID-19 salgını korkusu ve belirsizliği nedeniyle artan oranda çevrimiçi alışverişe devam etmeyi planladıklarını belirtmektedir (Retail customer experience, 2020).

Tüketim davranışı değişikliğinin arkasındaki en kritik değişkenin psikolojik faktörler olabileceği görülmektedir. İşletmelerin uzun vadede varlıklarını sürdürebilmeleri için tüketici satın alma davranışında değişikliğe neden olan psikolojik faktörleri analiz etmeleri ve buna uygun stratejiler oluşturmaları gerekmektedir. COVID-19 pandemisinin belirsizlik ve endişe verici koşullarında ortaya çıkan psikolojik durumların rasyonel ve ekonomik satın alma kararlarını neden ve nasıl değiştirdiğine dair çalışmalar sınırlı sayıdadır.

Sağlık tehditlerinin insan davranışı üzerindeki psikolojik etkisi, davranışsal değişikliklerin algılanan tehditten etkilendiğinin ortaya konduğu Sağlık inanç modeli ve tehdidi en aza indirmek veya önlemek için gereken eylemlerin yer aldığı SOR modeli ile açıklanmıştır.

Mevcut çalışmada Uyaran-Organizma-Tepki (S-O-R) paradigması ve Sağlık İnanç Modeli çerçevesinde, COVID-19' un yarattığı panik durumunda algılanan tehdit ve algılanan kaygının tüketicilerin dürtüsel satın almaları üzerindeki etkisi ve bu etkileşimde algılanan duyarlılık ve algılanan ciddiyetin düzenleyici rollerinin ortaya çıkarılması amaçlanmıştır.

\section{Kavramsal çerçeve ve teorik altyapı}

\section{S-O-R paradigması}

S-O-R paradigması Mehrabian ve Russell tarafından (1974) geliştirilmiştir. Model, çevresel uyaranlar ile duyguların bireylerin davranışları üzerinde etkisi olduğunu öne sürmektedir. S-O-R modeli, bir olayın davranışsal sonucuna karar veren uyarıcı (stimulus), organizma (organism) ve tepki (reason) olmak üzere üç yapıdan oluşmaktadır. Bu bağlamda modelde yer alan uyarıcı, çevresel unsurlar olarak, organizma, uyarıcı ve tepkiler arasındaki ilişkide aracı rolü olan unsurlar olarak; tepki ise tüketicilerin reaksiyonları olarak kullanılmaktadır. Paradigma; birey, durum ve karar verme etkileşimini açıklamaktadır.

Mehrabian ve Russell (1974), çevredeki duyusal faktörlerin bireylerin duygusal tepkilerini uyandırabileceğini ve bu durumun kişilerin çevreye yaklaşmalarını veya kaçınmalarını sağlayabileceğini öne sürmüştür. Mehrabian ve Russel oluşturdukları modelde, çevrede yer alan bütün elemanları, bireyin içsel durumlarını ve duygularını uyaran öncüller olarak kabul etmekte, bu etkileşim neticesinde bireyin çevreye yönelik yakınlaşma ve kaçınma gibi nihai tepkiler geliştirdiğini ortaya koymaktadır.

Çevresel ipuçları ve bunların bireylerin iç durumları ve davranışsal tepkiler üzerindeki ilgili etkileri arasındaki ilişki, bir dizi olay, uyarıcı-organizma-tepki (S-O-R) olarak ifade edilmiştir. Mehrabian ve Russell (1974) 'in çerçevesinde, uyaranlar (S) belirli bir ortamdaki bir dizi duyusal değişkeni ve bu 
uyaran bileşenleri arasındaki uzamsal ve zamansal ilişkileri karakterize eden bilgi yükünü temsil etmektedir. Organizma koşulları (O), çevresel uyaranlara karşı duygusal tepkileri, Tepkiler (R) ise, yaklaşma veya kaçınma davranışlarını temsil etmektedir.

Mehrabian ve Russell (1974)'a göre SOR modeli, “çevrenin çeşitli yönlerinin, birlikte insanların iç durumlarını etkileyen ve organizma $(\mathrm{O})$ olarak hareket eden ve dolayısıyla davranışsal tepkilerini $(\mathrm{R})$ yönlendiren uyarıcı (S) olarak hareket ettiğini açılamaktadır." Skinner (1935), uyarıcı ve tepki kavramını "davranışın ve çevrenin parçaları" olarak tanımlamıştır. Çevredeki ani değişiklikler, davranış değişikliklerini ileri taşıyarak bireylerin psikolojik ve duygusal dengesini etkileyebilmektedir (Donovan ve Rossiter, 1982). Uyaran, bir bireyin psikolojik durumunu etkileyip harekete geçiren diş güçlerdir (Peng ve Kim, 2014).

S-O-R paradigması, tüketici davranışı araştırmalarında kapsamlı bir şekilde uygulanmış (Islam, Sheikh, Hameed ve Khan, 2018; Liu, Chu, Huang ve Chen, 2016; Zhang, Lub, Gupta ve Zhao, 2014) ve COVID19 salgını sırasında tüketicilerin tepkilerini analiz etmede etkili olduğu kanıtlanmıştır (Laato, Islam, Farooq ve Dhir, 2020). Zheng, Miao,Lim, Li, Nie ve Zhang, (2020) ve Pandita, Mishra ve Chib (2021) SO-R paradigmasını COVID-19 döneminde tüketici davranışlarındaki değişimi açıklamak için kullanmışlardır.

Mevcut çalışma bağlamında uyaran, COVID-19 salgınının tüketicilerin algılanan tehdit durumunu etkileyen özelliklerini yansıtmaktadır. Bagozzi (1986), organizmayı "kişinin dışındaki uyaranlar ile ortaya çıkan nihai eylemler, tepkiler veya tepkiler arasında araya giren iç süreçler ve yapılar olarak tanımlamıştır. Araya giren süreçler ve yapılar, algısal, fizyolojik, hissetme ve düşünme etkinliklerinden oluşmaktadır". Fu , Chen ve Zheng (2020), organizmayı "uyaranın iç süreçleri ve sonuçları, genellikle uyaran ve tepki arasındaki ilişkiye aracılık eden" olarak tanımlamıştır. Organizma, uyaranla karşılaştıktan sonraki içsel duyguyu ve psikolojik süreci temsil etmektedir. Dolayısıyla bu çalışmada organizma, tüketicilerin COVID-19 salgınına karşı duygusal tepki olarak kaygı durumlarını ifade etmektedir. Hastalığın tehdidinin pandemi bağlamındaki ilk birincil çevresel uyaran olduğu düşünülmektedir. COVID-19 tehdidine yanıt olarak, birçok kişi kaygı duymaktadır. Modelde yer alan tepki, bir bireyin olumlu veya olumsuz olabilecek nihai davranışsal sonucunu ifade etmektedir (Donovan ve Rossiter, 1982; Spence, 1950). Bu bağlamda tepki, COVID-19 salgınına bir yanıt olarak tüketicilerin dürtüsel satın almalarını temsil etmektedir. S-O-R modeline göre, çevresel uyaran olarak algılanan tehdit (S) kaygıyı (O) etkilemekte, oluşan kaygı da buna bağlı olarak tüketicilerin dürtüsel satın almalarına (R) neden olmaktadır.

\section{Uyarıcı (Stimuli (S))-algılanan tehdit}

Tehdit, dış ortamda var olan zarar veya riski ifade etmektedir. Farklı kişiler farklı tehdit algısına sahiptir ve algilar bireylerin kişisel özelliklerine ve geçmiş deneyimlerine göre değişmektedir. Bu nedenle algılanan tehdit, kişilerin tepkilerini anlamak için oldukça önemlidir (Slovic, Fischhoff ve Lichtenstein, 1982). Bireyler bir tehdidin varlığını algıladıklarında, tehdit edici olayın işlenmesi bireyler üzerinde kaygı uyandırabilmektedir (Butler ve Mathews, 1987). Bu çevresel uyaranlar, bireylerin içsel durumlarını etkilemektedir. COVID-19 salgını sırasında tüketicilerde, depresyon, kaygı ve stres gibi psikolojik durumlar ortaya çıkmıştır (Cao, Fang, Hou, Han ve Xu, 2020; Duan ve Zhu, 2020; Wang, Pan, Wan, Tan, Xu, Ho ve Ho, 2020). Wen, Sun, Li, He ve Tsai (2019), bir sağlık krizi sirasında bireylerin tehdit algısının arttığını ifade etmiştir. Bir birey tarafından algılanan tehdit derecesi, bir hastalığın sonuçlarıyla ölçülebilen hastalık tehdidine ilişkin değerlendirmesiyle belirlenmektedir.

Beck ve Clark (1997), kaygının bir organizmanın çevredeki tehdit edici uyaranların seçici olarak işlenmesine verdiği yanıt olduğunu ifade etmiştir. Örneğin, Zhao ve Cai (2009), sigara içenlerin, algıladıkları akciğer kanseri tehdidinin, sağlık bilgisi arayışındaki kaygılarıyla olumlu bir şekilde ilişkili olduğunu ortaya koymuştur.

\section{Organizma (Organism (O))-kayg1}

Hızla yayılan salgın gibi tehditler çoğu zaman bireylere rahatsızlık ve gerginlik hissettirmektedir (Zheng, Lippke, Chen, Li ve Gan, 2019). Önceki araştırmalarda, salgın hastalıkların yüksek düzeyde kaygı ile ilişkili olduğu ortaya konmuştur. Örneğin, SARS salgını birçok ülkede kaygı ve sosyal sorunlara neden olmuştur (Bergeron ve Sanchez, 2005). Benzer şekilde Rubin, Amlot, Page ve Wessely (2009), İngiliz hükümetinin domuz gribi hakkında yayınladığı broşürü okuyan kişilerin yüksek düzeyde kaygı bildirdiklerini tespit etmiştir. H1N1 influenza salgını sırasında kişilerin kaygı düzeylerinde önemli bir artış olduğu tespit edilmiştir.

Amerikan Psikoloji Derneği (APA) kaygıyı (anksiyete), "bir bireyin yaklaşan tehlike veya felaketi beklediği, kaygı ve somatik gerilim semptomları ile karakterize edilen bir duygu" olarak 
tanımlamaktadır (Amerikan Psikoloji Derneği, 2021). Pandemi sırasında bu semptomlar şiddetlenebilmektedir. Sağlık endişesi, korkulan bir hastalığın ne kadar olası ve ne kadar şiddetli olarak algılandığına bağlıdır (Wheaton, Berman, Franklin ve Abramowitz, 2010). COVID-19'un kolayca bulaşan bir virüs olarak resmedilmesi kişilerin yüksek oranda maruz kalma ve enfekte olma olasilığ1 algisını tetiklemektedir ve kaygı düzeylerini artırmaktadır (De Pietri ve Chiorri, 2021: 3).

\section{Tepki (Response (R)) -dürtüsel satın alma}

Dürtüsel satın alma literatürde genellikle uyaranlarla tetiklenen, spontane, ani, istem dışı ve düşünmeden gerçekleştirilen satın alma olarak tanımlanmaktadır (D'Antoni Jr ve Shenson, 1973; Rook, 1987). Peck ve Childers (2006) dürtüsel satın almayı " kendiliğinden, düşünmeden ve aniden gerçekleşen satın alma eğilimi" olarak tanımlamışır.

Dürtüsel satın almayı etkileyen faktörler; kişisel faktörler, çevresel faktörler ve ürün ile ilgili faktörler olmak üzere üç grupta incelenmektedir. Psikolojik olarak dengesiz olmak ve sonuçlarını düşünmeden aniden eyleme geçme isteği kişisel faktörler arasında yer almaktadır (Rook ve Hoch, 1985; Sofi ve Nika, 2017). Düşük fiyat, ürün promosyonları, görsel uyaranlar ve ekonomik durum, çevresel faktörler arasında yer almaktadır (Dittmar, 2005: 474). Dürtüsel satın almayı etkilediği düşünülen ürün ile ilgili faktörler, ürünün satın alınması ile elde edileceği düşünülen faydalardır (Prakash ve Sharma, 2016: 32).

Önceki araştırmalar, dürtüsel satın almanın duygulanım veya duygusal durum gibi çeşitli psikolojik faktörlerden kaynaklandığını ortaya koymuştur (Verplanken, Herabadi, Perry ve Silvera, 2005; Mohan, Sivakumaran ve Sharma, 2013; Bellini, Cardinali ve Grandi, 2017). Olumsuz duygu durumları dürtüsel satın almaya neden olabilmektedir (Šeinauskienė, Maščinskienè ve Jucaitytė,, 2015). Addo, Jiaming, Kulbo ve Liangqiang (2020), dürtüsel satın almanın bireylerin düşük güven, olumsuz duygusal durumlar ve olumsuz zihinsel düşünme ile başa çıkmalarına yardımcı olabileceğini ifade etmiştir.

Dürtüsel satın alma olgusu, genellikle acil durum, hastalık ve kriz olaylarında (örneğin, SARS salgını ve influenza A-H1N1) ortaya çlkmaktadır (Xiao , Zhang ve Zhang, 2020). Tarihsel olarak dürtüsel satın almanın ilk olarak 1918'deki İspanyol gribi salgını sırasında ortaya çıktığı bilinmektedir (Honigsbaum, 2013). Ardından, SARS (Şiddetli Akut Solunum Sendromu) salgını sırasında (Cheng, 2004; Fast, González, Wilson ve Markuzon, 2015) ve nükleer kriz gibi doğal olmayan afetlerde (Liu, Chu, Huang ve Chen, 2020) meydana geldiği gözlemlenmiştir. Benzer şekilde korku uyandıran COVID-19 fenomeni bağlamında, dürtüsel satın alma davranışı dünyada önemli ölçüde artmıştır (Addo vd., 2020; Kim, 2020).

Valence, D'Astous ve Fortier (1988) tüketici kaygısının dürtüsel satın almanın merkezinde yer aldığını ifade etmişlerdir. Slickdeals (2020), tüketicilerin salgının öncesine kıyasla COVID-19 salgını sırasında daha fazla dürtüsel alışveriş yaptıklarını ortaya koymuştur. Xiao , Zhang ve Zhang (2020), COVID-19 döneminde kaygının dürtüsel satın alma üzerinde olumlu etkiye sahip olduğunu tespit etmişlerdir. Benzer şekilde Naeem (2021), hastalık korkusunun tüketiciler arasında dürtüsel satın alma davranışını artırdığını ortaya koymuştur.

Mevcut literatür incelendiğinde, dürtüsel satın almanın duygu ile ilgili bir davranış olduğu açıkça görülmektedir. Ek olarak, COVID-19 örneğinde olduğu gibi belirli bir acil durum ve kriz bağlamında, kişiler kaygılarını azaltmak için kendilerini rahatlatmanın bir yolu olarak dürtüsel satın alma eğilimini artırmaktadırlar (Müller, Mitchell, Crosby, Cao, Johnson, Claes ve Zwaan, 2012).

\section{Sağlık inanç modeli}

Sağlık inanç modeli, 1950'lerde sağlık eğitimi programlarının etkililiğini anlamak için ortaya çıkmıştır (Sheeran ve Abraham, 1996). Sağlık davranışlarının açıklanmasında kullanılan Sağlık İnanç Modeli, bireylerin sağlıklı olmalarının onlar açısından neyi ifade ettiğinin ortaya çıkarılmasını sağlamaktadır.

Sağlık İnanç Modeli, algılanan bir tehdit nedeniyle sağlıkla ilgili davranışların nasıl geliştiğini açıklamaktadır (Sreelakshmi ve Prathap, 2020: 353). Model, demografik değişkenleri ve psikolojik özellikleri, algılanan duyarlılık, algılanan ciddiyet, sağlık motivasyonu ve algılanan faydalar gibi duygusal ve bilişsel durumlarla ilişkilendirmektedir (Sheeran ve Abraham, 1996). Sağlık İnanç Modeline göre, algılanan duyarlılık ve algılanan ciddiyetle ölçülen algılanan hastalık tehdidi, algılanan faydalar, algılanan engeller ve algılanan öz yeterlik, sağlık davranışının gelişimini teşvik etmektedir (Becker ve Maiman, 1980). Modelde algılanan tehdit iki boyuttan oluşmaktadır: algılanan duyarlılık ve hastalığın algılanan ciddiyeti (Champion ve Skinner, 2008: 47).

Sağlık İnanç Modeli, sağlıkla ilgili müdahaleler için sağlıkla ilgili davranışların değişimini ve sürdürülmesini açıklayan, sağlık davranışı araştırmalarında yaygın olarak kabul gören bir modeldir. Önceki çalışmalar, bu yapıların pandemi durumlarında sağlık motivasyonu için önemli belirleyiciler 
olduğunu ortaya koymuştur (Bish ve Michie, 2010; Farooq, Laato ve Islam, 2020).

Mevcut çalışma bağlamında, dürtüsel satın alma, COVID-19 virüsünden etkilenme olasılığını kontrol altına almaya yardımcı olan önleyici bir tüketici davranışı olarak düşünülmektedir.

\section{Algilanan duyarlılık}

Algılanan duyarlılık, bireylerin sağlıklarını tehdit eden durumları nasıl algıladıklarını açıklamaktadır. Başka bir deyişle, bireylerin kendilerini risk altında görme olasılıkları ile ilişkilidir (Ling, Kothe ve Mullan, 2019). Champion (1984), algılanan duyarlılığı, "bir kişinin potansiyel olarak zararlı bir durumu yaşama olasılığına ilişkin görüşü" olarak tanımlamaktadır.

Algılanan duyarlılık, bir hastalığa veya duruma yakalanma olasılığı hakkındaki inançları ifade etmektedir. Algılanan duyarlılığın artması durumunda, bireyin riski azaltma yönünde davranış gösterme eğilimi de artmaktadır (Champion ve Skinner, 2008: 47). Kişi kendisini herhangi bir durum karşısında ne kadar fazla risk altında hissederse, sağlığı açısından kendisine risk oluşturacak davranışını da aynı oranda azaltma eğiliminde olacaktır (Hayden 2009).

\section{Algılanan ciddiyet}

Algılanan ciddiyet, bireyin sağlık sonuçlarına göre durumun ciddiyetini değerlendirmesidir (Lin vd., 2019). Başka bir ifadeye göre algılanan ciddiyet, "durumun, kişi için ne kadar tehdit edici olduğu" anlamina gelmektedir (Champion, 1984; Sreelakshmi ve Prathap, 2020). Algılana ciddiyet bireyin sağlik bilgisinden etkilenmektedir. Kişi hastalık hakkında bilgi sahibi ise algısı da bununla ilişkili olarak değişmektedir. Bireyin hastalık ile ilgili bilgisinden etkilenen ciddiyet algısı, hastalığın sonuçları (ölüm, sakat kalma vb.) ile ilgili değerlendirmelerini kapsamaktadır (Hayden 2009).

Algılanan ciddiyet, risk algısını etkileyerek, bir hastalığa karşı ihtiyati tedbirler almak için motivasyon yaratmaktadır (Rogers, 1975). Sağlık İnanç Modeline göre, hastalığın algılanan tehdidi büyükse, bireylerin uygun önlemi alma olasılığı daha yüksek olmaktadır. Buna karşlık, algılanan ciddiyet daha fazlaysa, yani hastalık ciddi bir sorun olarak kabul edilirse, algılanan tehdit daha büyük olacaktır. Bu nedenle, COVID-19 salgını durumunda, algılanan ciddiyetin, dürtüsel satın alma üzerinde etkisi olduğu düşünülmektedir.

\section{Hipotez geliştirme}

Önceki çalışmalar, SARS ve MERS vakalarında olduğu gibi, bireylerin sağllğı tehdit eden acil durumlarda kendilerini kaygılı hissettiklerini göstermektedir (Hawryluck, Gold, Robinson, Pogorski, Galea ve Styra, 2004; Jeong, Yim, Song, Ki, Min, Cho ve Chae, 2016). Wang vd. (2020), Çinli katılımcıların \%28,8'inin COVID-19 salgını sırasında orta ve şiddetli derecede kaygılı hissettiklerini belirtmişlerdir. Benzer şekilde Song, Yao ve Wen (2021), COVID-19 salgınının algılanan tehdidinin, kaygı ile olumlu bir şekilde ilişkili olduğunu tespit etmişlerdir. Shahzad, Du, Khan, Fateh, Shahbaz, Abbas ve Wattoo (2020) ve Paredes, Apaolaza, Fernandez, Hartmann ve Yañez-Martinez (2021), COVID-19'un algilanan tehdidinin algılanan kaygı üzerinde etkisi olduğunu ortaya koymuşlardır. Zheng vd. (2020), SOR modeli çerçevesinde COVID-19 salgını tehdidin kaygı üzerinde etkili olduğunu kanıtlamışlardır. Bu bilgiler ışı̆̆ında COVID-19 salgınının algılanan tehdidinin kaygı üzerinde etkisi olduğu öngörülmektedir.

$\boldsymbol{H}_{1}$ : COVID-19 salgımını algılanan tehdidinin, kaygı üzerinde etkisi vardır.

COVID-19 döneminde bireylerin kaygı düzeylerinin artması, tüketicilere dürtüsel satın alımlar yaparak hazırlık yapma dürtüsü hissettirmektedir. Laato vd. (2020) ve Xiao , Zhang ve Zhang (2020), COVID-19 döneminde tüketicilerin hissettikleri kaygının, dürtüsel satın almayı etkilediğini tespit etmiştir. Benzer şekilde, Pandita, Mishra ve Chib (2021), SOR modeli çerçevesinde COVID-19 döneminde üniversite öğrencilerinin davranışsal psikolojik değişikliklerini inceledikleri çalışmalarında, öğrencilerin hissedikleri endişe ve korkunun dürtüsel satın almaya sebep olduğu sonucunu ortaya koymuşlardır. Bu kapsamda kaygının dürtüsel satın alma üzerinde etkisi olduğu öngörülmektedir.

$\mathrm{H}_{2}$ : Kaygının dürtüsel satın alma üzerinde etkisi vardır.

Algılanan duyarlılı̆̆ın yüksek olduğu durumlarda, algılanan tehdit de yüksek olmaktadır (Carico, Sheppard ve Thomas, 2021: 1985). Sağlık İnanç Modeline göre algılanan tehdit, algılanan duyarlılık ve algilanan ciddiyetten oluşmaktadır. Model hem algılanan duyarlılığın hem de algılanan ciddiyetin, sağlık riskleri karşısında insan davranışının başlıca itici güçleri olduğunu varsaymaktadır (Sheeran ve Abraham, 1996). Bu bilgiler doğrultusunda algılanan tehdidin kaygı ve kaygının dürtüsel satın alma üzerindeki etkisinde algılanan duyarlılığın düzenleyici etkisi olduğu öngörülmektedir.

$\mathrm{H}_{3}$ : Algılanan tehdidin, kaygı üzerindeki etkisinde algılanan duyarlılı̆̆ı düzenleyici etkisi vardır. 
$\mathbf{H}_{4}$ : Kaygının, dürtüsel satın alma üzerindeki etkisinde algılanan duyarlılı̆̆ın düzenleyici etkisi vardır.

Önceki çalışmalar, algılanan ciddiyetin, akut sağlık sorunları (Ruthig, 2016) ve pandemiler (Bults, Beaujean, Richardus ve Voeten 2015) gibi yaşamı tehdit eden hastalıklara karşı önlem alma niyetini önemli ölçüde öngördüğünü ortaya koymaktadır. Goodwin, Haque, Neto ve Myers (2009), domuz gribi salgını nedeniyle bireylerin yiyecek alımlarının arttığını tespit etmiştir. Joshi ve Rahman (2015), algilanan ciddiyetin tüketici davranışları üzerinde etkisi olduğunu ortaya koymuştur. Benzer şekilde Laato vd. (2020), algılanan ciddiyetin dürtüsel satın alma üzerinde etkisi olduğunu tespit etmişlerdir. COVID-19 salgını durumunda, algılanan ciddiyetin dürtüsel satın alma üzerinde bir etkisi olduğu düşünülmektedir. Tüketiciler hastalığı ne kadar ciddiye alır ve duyarlı davranırlarsa, hastalık tehdidinin kaygı üzerindeki etkisini ve kaygının dürtüsel satın alma üzerindeki etkisini güçlendirirler. Bu bilgiler doğrultusunda algılanan tehdidin kaygı üzerinde ve kaygının dürtüsel satın alma üzerindeki etkisinde algılanan ciddiyetin düzenleyici etkisi olduğu öngörülmektedir.

$\mathrm{H}_{5}$ : Algılanan tehdidin, kaygı üzerindeki etkisinde algllanan ciddiyetin düzenleyici etkisi vardır.

$\boldsymbol{H}_{6}$ : Kaygının, dürtüsel satın alma üzerindeki etkisinde algllanan ciddiyetin düzenleyici etkisi vardır.

\section{Araştırma metodolojisi}

\section{Araştırmanın amacı ve önemi}

Bu çalışmada S-O-R Paradigması ve Sağlık İnanç Modeli kapsamı altında oluşturulan modelde, COVID19 kapsamında algılanan tehdidin kaygı üzerinde ve kaygının tüketicilerin dürtüsel satın almaları üzerindeki etkisinde algılanan ciddiyet ve algılanan duyarlılığın düzenleyici etkilerinin incelenmesi amaçlanmıştır. Risk algısı hakkındaki önermelere dayanarak, Sağlık İnanç Modelinden algılanan sağlık tehdidinin iki alt boyutu olan algılanan duyarlılık ve algılanan ciddiyet düzenleyici değişken olarak modele dahil edilmiştir.

S-O-R paradigması, çevresel psikoloji çerçevesinde değerlendirilen, çevresel uyaranlar ile duyguların bireylerin davranışları üzerine etkisi olduğunu öne süren bir modeldir (Mehrabian ve Russell, 1974). Uyarıcı (Stimulus), Organizma (Organism) ve Tepki (Response) olarak incelenen model, tüketici davranışlarını inceleyen birçok çalışmada temel alınmıştır. Sağlık İnanç Modeli, bireylerin sağlık davranışlarının değer, tutum ve inançlarından etkileneceğini iddia etmektedir. Model sağlık davranışlarını etkileyen faktörleri ortaya çıarmada en çok tercih edilen modeldir (Rohleder, 2012). Bu kapsamda yapılan çalışmalarda COVID-19 pandemisinin psikolojik etkileri ile ilgili teorik araştırmaların sınırlı sayıda olması araştırmanın önemini ortaya koymaktadır. Önerilen model, S-O-R paradigması ve Sağlık İnanç Modelini entegre ederek, algılanan tehdidin, kaygı durumunu etkilediğini ve kaygının dürtüsel satın almayı etkilediğini, algılanan ciddiyet ve algılanan duyarlılı̆̆ın bunlar üzerinde düzenleyici etkisi olduğunu varsaymaktadır.

\section{Anakütle ve örneklem}

Çalışmanın ana kütlesini COVID-19 testi yaptırmış ve negatif sonuçlanmış bireyler ile henüz test yaptırmamış ama belirtileri taşımayan Türkiye' deki bireyler oluşturmaktadır. Ana kütlenin tamamına erişmek mümkün olmadığından örnekleme yöntemi kullanılmış ve çalışma 403 katılımcı üzerinde gerçekleştirilmiştir. Örneklem yöntemi olarak tesadüfi olmayan örneklem yöntemlerinden kolayda örnekleme ve kartopu örnekleme kullanılmıştır.

Örneklem büyüklüğünün hesaplanmasında, ana kütlenin 1 milyon ve üzerinde olduğu ve örneklem hata oranının $\pm 0,05$ düzeyinde olduğu durumlarda 384 örneklem sayısının yeterli olacağını belirten yaklaşım kullanılmıştır (Yazıcıŏ̆lu ve Erdoğan, 2004: 50). Bu kapsamda değerlendirildiğinde veri toplama süreci sonunda elde edilen 403 katılımcıya ait veri yeterli kabul edilmiş ve çalışma bu veriler üzerinden analiz edilmiştir.

\section{Veri toplama araç ve yöntemi}

Araştırmaya veri toplamak amacıyla Google Forms üzerinden online anket formu hazırlanmıştır. Veri toplama sürecinin online gerçekleştirilme nedeni hem maliyet ve zaman açısından uygun olması hem de COVID-19 sürecinde yüz yüze uygulama zorluğunu ortadan kaldırmasıdır. Oluşturulan anket formunda demografik sorular ile birlikte algılanan duyarlılık, algılanan ciddiyet, algılanan tehdit, kayg1 ve dürtüsel satın alma ölçek ifadelerine yer verilmiştir.

Veri toplama süreci 4 Ocak-15 Ocak 2021 tarihleri arasında gerçekleştirilmiştir. Sağllk bakanlığ1 verilerine göre ilgili tarihler arasında toplam vaka sayısı 131.203, günlük ortalama vaka sayısı 10934, toplam vefat 2345, günlük ortalama vefat sayısı 196 kişi olarak gerçekleşmiştir (www.covid19.saglik.gov.tr). Veri toplama sürecine başlamadan önce İstanbul Ticaret Üniversitesi Etik 
Komisyonundan gerekli onay alınmıştır (Sayı: E-65836846-044-202499).

\section{Kullanılan ölçekler}

Anket formunda yer alan ölçeklerden algılanan ciddiyet ve algılanan duyarlılık için Farooq vd. (2020) ve Ling vd. (2019), kaygı ölçeği için Marteau ve Bekker (1992), algılanan tehdit için Yang (2012) ve Lin ve Bautista (2016)'nin çalışmalarından yararlanılmıştır. Son olarak dürtüsel satın alma ölçeği Verhagen ve van Dolen (2011)'nin çalışmalarından alınmıştır ve COVID-19 dönemine yönelik düzenlenmiştir. Tüm maddeler, yanıtlayanların her bir ifadeye yönelik tutumunu test etmek için 1'den (kesinlikle katılmıyorum) 5'e (kesinlikle katılıyorum) kadar değişen beşli Likert ölçeğine göre derecelendirilmiştir.

\section{Araştırma modeli}

Araştırma modeli oluşturulurken S-O-R paradigması ve Sağlık İnanç Modeli esas alınmıştır. SOR modeli için uyarıcı olarak algılanan tehdit, organizma olarak kaygı ve tepki olarak dürtüsel satın alma kullanılmıştır. Sağlık İnanç Modeli temelinde ise, bireylerin sağlık riskiyle karşı karşıya kalmalarını durumunda davranışlarını yönlendiren değişkenler olarak ele alınan algılanan ciddiyet ve algılanan duyarlılık, bu ilişkilerde düzenleyici etkiye sahip olabilecek düzenleyici değişkenler olarak modelde yer almıştır. Önerilen model çerçevesinde, tüketicilerin COVID-19'un algılanan tehdidinin, oluşan kaygı durumu üzerinde etkisinin olduğu ve kaygının tepki davranışı olarak dürtüsel satın almaya yol açtığı ve bu etkileşimlerde COVID-19'un algılanan ciddiyetinin ve duyarlılığının düzenleyici role sahip olacağı, bu etkileşimleri güçlendireceği öngörülmüş̧tür. Önerilen araştırma modeli Şekil 1'de gösterilmektedir.

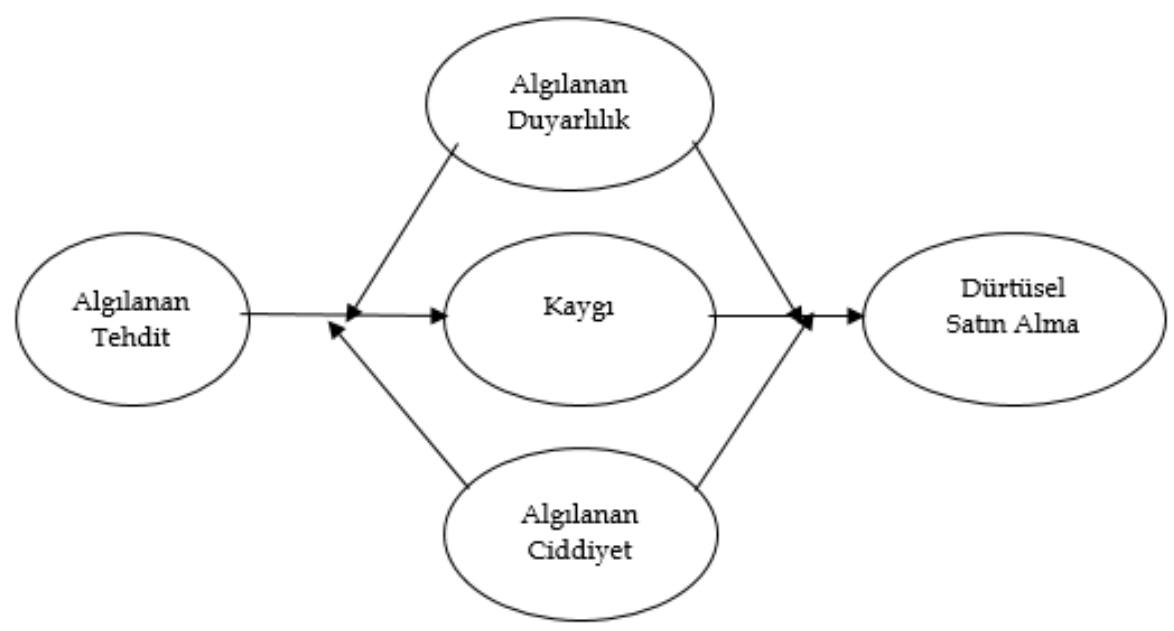

Şekil 1: Araştırma Modeli

\section{Veri analizi}

Elde edilen verilerin analizinde tanımlayıcı istatistikler, güvenilirlik testi ve korelasyon sonuçları için SPSS 24 programı, modelde yer alan ilgili değişkenlerin geçerlilik ve güvenilirliğinin incelenmesi için doğrulayıcı faktör analizleri, araştırma modelindeki hipotezlerin test edilmesi için AMOS 24 yapısal eşitlik modeli yol analizleri kullanılmıştır. Analize başlamadan önce katılımcı verilerinde uç değer olup olmadığının incelenmesine yönelik outlier analizi gerçekleştirilmiş, normallik varsayımı sınanmıştır.

Uç değerler, istatistiksel testlerdeki rolü nedeniyle varlığı araştırılması ve veri setinden çıkarılması gereken değerlerdir (Hair, Black, Babin, Anderson ve Tatham, 2006). SPSS'de oluşturulan kutu grafiği ve gövde yaprak grafikleri uç değerleri incelemek için kullanılır (Mooi ve Sarstedt, 2011). Analiz sonuçlarında katılımcılar için uç değer tespit edilmemiştir.

Normallik varsayımının incelenmesinde Shao (2002) tarafından önerilen, araştırma anket formunda yer alan ifadelerin basıklık ve çarpıklık katsayılarının +3 ile -3 arasında olması durumunda normallik varsayımı kabul edilebilir görüşü değerlendirilmiş (Shao, 2002:424) ve tüm ifadelerin basıklık ve çarpıklık değerlerinin bu aralıklarda olması sonucu normallik varsayımının sağlandığı sonucuna ulaşılmiştır.

Araştırma modeline yönelik analizler yapılmadan önce incelenmesi gereken bir diğer durum ortak yöntem yanlılığıdır. Ortak yöntem yanlılığı, araştırma değişkenlerinin ölçülmesinde aynı kişiden aynı ölçüm ortamında aynı yöntem kullanıldığında değişkenler arasında ortaya çıkn yapay korelasyon miktarıdır ve bu değerin gerçek değerinden aşağı yada yukarı çıkması ortak yöntem yanlılı̆̆ı olduğunu göstermektedir (Fiske, 1982). Ortak yöntem yanlılığını incelemek için bazı istatistiksel teknikler 
kullanılmaktadır. Bu tekniklerden bazıları korelasyon değerlerinin yorumlanması ve doğrulayıcı faktör analizinde yapı geçerliliğinin sağlanmasıdır. Değişkenler arasındaki tüm korelasyon katsayılarının 0.90'dan fazla olmadığı ve doğrulayıcı faktör analizi sonrası yapı geçerliliğinin kabul edildiği durumlarda ortak yöntem yanlılığı olmadığı kabul edilmektedir (Özyılmaz ve Eser, 2013: 505; Podsakoff, MacKenzie ve Podsakoff, 2012; Richardson, Simmering ve Sturman, 2009; Tehseen, Ramayah ve Sajilan, 2017: 162). Bu çalışmada yapılan korelasyon analizi sonucu ilişki katsayılarının 0,90'dan az çıkması ve doğrulayıcı faktör analizi ile yapı geçerliliğinin sağlanması ortak method varyansı olmadığını göstermektedir.

\section{Bulgular}

\section{Demografik bulgular}

Tablo 1. Katılımcılara Yönelik Demografik Özellikler

\begin{tabular}{|c|c|c|c|c|c|}
\hline Cinsiyet & Say1 & Yüzde & Medeni durum & Say1 & Yüzde \\
\hline Kadın & 210 & 52,1 & Bekar & 207 & 51,4 \\
\hline Erkek & 193 & 47,9 & Evli & 196 & 48,6 \\
\hline Toplam & 403 & 100,0 & Toplam & 403 & 100,0 \\
\hline Yaş & Say1 & Yüzde & Çocuğa sahip olma & Say1 & Yüzde \\
\hline 20 yaş altı & 49 & 12,2 & 1 & 60 & 14,9 \\
\hline $20-24$ & 80 & 19,8 & 2 & 91 & 22,6 \\
\hline $25-34$ & 100 & 24,5 & 3 & 70 & 17,4 \\
\hline $35-44$ & 86 & 21,4 & 4 ve üzeri & 18 & 4,5 \\
\hline $45-54$ & 41 & 10,4 & Yok & 164 & 40,7 \\
\hline $55-64$ & 22 & 5,5 & Toplam & 403 & 100,0 \\
\hline 65 yaş ve üzeri & 25 & 6,2 & COVID-19 test yaptırma durumu & Say1 & Yüzde \\
\hline Toplam & 403 & 100,0 & Yaptırdım, negatif & 145 & 36,0 \\
\hline Öğrenim durumu & Say1 & Yüzde & Yaptırmadım & 258 & 64,0 \\
\hline Doktora & 19 & 4,7 & Toplam & 403 & 100,0 \\
\hline İlk ve Ortaöğretim & 5 & 1,2 & & & \\
\hline Lisans & 151 & 37,5 & & & \\
\hline Lise & 81 & 20,1 & & & \\
\hline Önlisans & 60 & 14,9 & & & \\
\hline Yüksek Lisans & 87 & 21,6 & & & \\
\hline Toplam & 403 & 100,0 & & & \\
\hline
\end{tabular}

Araştırma örnekleminde yer alan katılımcıların demografik özelliklerini gösteren Tablo 1 incelendiğinde, $\% 52,1$ oranla kadın, $\% 47,2$ oranla erkek katılımcıların, $\% 51,4$ oranla bekar, $\% 48,6$ oranla evli katılımcıların örneklemde yer aldığı görülmektedir. Katılımcıların \%40,7'sinin çocuk sahibi olmadığı, çocuğu olanların ise sirasıyla \%22,4'ünün 2, \%17,4'ünün 3, \%14,9'unun 1 çocuğa sahip oldukları, yaklaşık yarıya yakının 25-44 yaş arasında oldukları tespit edilmiştir. Öğrenim durumları incelendiğinde çoğunluğun yarısından fazlasının lise ve lisans mezunu oldukları belirlenmiştir. COVID-19 testi yaptırma durumları değerlendirdiğinde, örneklemde yer alan katılımcıların \%64'ünün test yaptırmadığı, \%36'sının test yaptırdığı ve negatif sonuçlandığı görülmektedir.

\section{Doğrulayıcı faktör analizi ve ölçek güvenilirlik ve geçerlilik test sonuçları}

Çalışmada kullanılan ölçeklerin faktör yapılarının ve yapı geçerliklerinin test edilmesinde doğrulayıcı faktör analizi kullanılmıştır. Faktör analizi sonuçlarının incelenmesinde öncelikle uyum iyiliği değerlerine bakılmaktadır. Bazı araştırmacılar (Jöreskog ve Sörbom, 1984; Meydan ve Şeşen, 2011) tarafından önerilen bu değerler için olması gereken aralıklar ve değerlendirme kriterleri Tablo 2 'de gösterilmiştir. 
Tablo 2. Doğrulayıcı Faktör Analizleri Uyum İyiliği Sonuçları

\begin{tabular}{llllll}
\hline Değişkenler & X² & GFI & AGFI & CFI & RMSEA \\
\hline Algılanan Tehdit & 1,03 & 0,99 & 1.00 & 0,98 & 0,02 \\
\hline Kayg1 & 1,21 & 1,00 & 0,98 & 0,97 & 0,03 \\
\hline Dürtüsel Satın Alma & 2,86 & 0,98 & 0,99 & 0,94 & 0,05 \\
\hline Algılanan Duyarlılık & 1,13 & 0,99 & 1,00 & 0,98 & 0,03 \\
\hline Algılanan Ciddiyet & 1,07 & 0,98 & 0,97 & 0,99 & 0,02 \\
\hline Uyum İyiliği Değerleri & X'/df & GFI & AGFI & CFI & \multirow{2}{*}{ RMSEA } \\
\hline İyi & $\leq 3$ & $\geq 0,90$ & $\geq 0,90$ & $\geq 0,97$ & $\leq 0,05$ \\
\hline Kabul Edilebilir & $\leq 4-5$ & $0,89-0,85$ & $0,89-0,80$ & $\geq 0,95$ & $0,06-0,08$ \\
\hline Kaynak: Jöreskog ve Sörbom & 1984, Meydan & & & &
\end{tabular}

Kaynak: Jöreskog ve Sörbom, 1984, Meydan ve Şeşen, 2011.

Ölçek faktör yapılarının doğrulanması için gerçekleştirilen doğrulayıcı faktör analizi sonuçlarında modelde yer alan her bir ölçeğin uyum iyiliği değerlerinin olması gereken aralıklarda yer aldıkları görülmektedir.

Ölçeklerin güvenirliğinin ve geçerliliğinin değerlendirilmesinde Cronbach alfa güvenilirlik katsayısı (Hair vd., 2006; Netemeyer, Bearden ve Sharma, 2003) ile geçerliliğin incelenmesinde birleşim ve ayrışım geçerlilik değerleri yorumlanmaktadır (Chin, Gopal ve Salisbury,1997). Test sonuçlarında birleşim (composite) geçerlilik değerinin (CR) 0,70 ve üzeri elde edilmesi yeterli kabul edilirken, ayrışım geçerlilik değeri için kullanılan ortalama açıklanan varyans değerinin (AVE-Average Explained Variance) 0,50'den fazla olması geçerliliğin sağlandığını göstermektedir (Fornell ve Larcker,1981). Güvenilirlik değeri Cronbach alfa değerinin ise 0,70 ve üzeri çıkması ölçek güvenilirliğinin sağlandığını ifade etmektedir (Altunışık, Coşkun, Bayraktaroğlu ve Yıldırım, 2012).

Tablo 3. Ölçek Faktör Yükleri, Güvenilirlik ve Geçerlilik Test Sonuçları

\begin{tabular}{|c|c|c|c|c|c|}
\hline Değişkenler & İfadeler & Faktör Yükleri & Cronbach Alfa & CR & AVE \\
\hline \multirow{3}{*}{$\begin{array}{l}\text { Algilanan } \\
\text { Tehdit }\end{array}$} & Koronavirüs salgını sağlığımı riske atıyor. & 0,841 & \multirow{3}{*}{0,840} & \multirow{3}{*}{0,872} & \multirow{3}{*}{0,773} \\
\hline & Yaşam kalitem için çok ciddi bir tehdit oluşturuyor & 0,858 & & & \\
\hline & $\begin{array}{l}\text { Hem psikolojik hem fiziksel açıdan sağlığıma zarar } \\
\text { veriyor }\end{array}$ & 0,911 & & & \\
\hline \multirow{5}{*}{ Kayg1 } & $\begin{array}{l}\text { Koronavirüs salgını ile ilgili haberler okurken kendimi } \\
\text { aşırı gergin hissediyorum. }\end{array}$ & 0,781 & \multirow{5}{*}{0,816} & \multirow{5}{*}{0,882} & \multirow{5}{*}{0,784} \\
\hline & Bu tür haberleri okuduğumda üzülüyorum. & 0,813 & & & \\
\hline & $\begin{array}{l}\text { Bu tür haberleri okuduktan sonra kendimi endişeli } \\
\text { hissediyorum. }\end{array}$ & 0,868 & & & \\
\hline & Bu tür haberleri okumaktan kendimi alıkoyamıorum. & 0,882 & & & \\
\hline & Bu tür haberleri okurken kendimi stresli hissediyorum. & 0,904 & & & \\
\hline \multirow{6}{*}{$\begin{array}{l}\text { Dürtüsel } \\
\text { Satın Alma }\end{array}$} & $\begin{array}{l}\text { Koronavirüs sürecinde, markete girdiğimde satın } \\
\text { almayı düşünmediğim şeyler satın alıyorum. }\end{array}$ & 0,761 & \multirow{6}{*}{0,911} & \multirow{6}{*}{0,791} & \multirow{6}{*}{0,804} \\
\hline & $\begin{array}{l}\text { Bir şeyler satın almak için acaba alsam mı şeklinde ani } \\
\text { dürtüler/uyarılar yaşıorum }\end{array}$ & 0,823 & & & \\
\hline & $\begin{array}{l}\text { Alışveriş listemde olmasa da satın almak istediğim bir } \\
\text { dizi ürünle ilgileniyorum. }\end{array}$ & 0,834 & & & \\
\hline & $\begin{array}{l}\text { Bazen, aniden bir şey satın alma gereksinimim olduğu } \\
\text { dürtüsü hissediyorum }\end{array}$ & 0,841 & & & \\
\hline & $\begin{array}{l}\text { Satın alma sürecim aslında kendiliğinden ve hızlıca } \\
\text { gerçekleşiyor, ne yaptığımı, neler aldığımı } \\
\text { bilemiyorum. }\end{array}$ & 0,862 & & & \\
\hline & $\begin{array}{l}\text { Çoğunlukla plansız satın alma davranışı } \\
\text { gösterebiliyorum }\end{array}$ & 0,871 & & & \\
\hline \multirow{3}{*}{$\begin{array}{l}\text { Algilanan } \\
\text { Duyarlılik }\end{array}$} & $\begin{array}{l}\text { Koronavirüse yakalanmaya karşı savunmasız } \\
\text { olduğumu düşünüyorum. }\end{array}$ & 0,680 & \multirow{3}{*}{0,717} & \multirow{3}{*}{0,806} & \multirow{3}{*}{0,742} \\
\hline & $\begin{array}{l}\text { Koronavirüse yakalanma ihtimalim olduğunu } \\
\text { sanmiyorum. }\end{array}$ & 0,702 & & & \\
\hline & $\begin{array}{l}\text { Koronavirüse yakalanma riskimin her zaman var } \\
\text { oluğunu düşünüyorum. }\end{array}$ & 0,781 & & & \\
\hline \multirow{3}{*}{$\begin{array}{l}\text { Algilanan } \\
\text { Ciddiyet }\end{array}$} & $\begin{array}{l}\text { Koronovirüsün olumsuz etkilerinin çok yüksek } \\
\text { olduğunu, ciddiyete alınması gerektiğini düşünüyorum }\end{array}$ & 0,822 & \multirow{3}{*}{0,812} & \multirow{3}{*}{0,783} & \multirow{3}{*}{0,791} \\
\hline & $\begin{array}{l}\text { Koronavirüsün yaşamımızı önemli derecede tehdit } \\
\text { ettiğini düşünüyorum. }\end{array}$ & 0,879 & & & \\
\hline & $\begin{array}{l}\text { Koronavirüsü benim gibi biri için ciddi bir tehdit olarak } \\
\text { görüyorum. }\end{array}$ & 0,891 & & & \\
\hline
\end{tabular}


Tablo 3, doğrulayıcı faktör analizi sonucu elde edilen ölçek ifadelerinin faktör yüklerini ve güvenilirlik ve geçerlilik değerlerini göstermektedir Doğrulayıcı faktör analizinde faktör yüklerinin incelenmesinde standardize edilmiş yol katsayıları kullanılmakta ve faktör yükleri 0,50 ' den az olan ifadeler analizden çıkarılmaktadır. Faktör yükü 0,50 'den az olan ifadeler olmaması yapı geçerliliğinin de sağlandığının göstergesidir (Hair vd., 2014). Kullanılan ölçekler için oluşan faktör yükleri incelendiğinde tüm değerlerin 0,50 ve üzeri çıkması nedeniyle ifade çıkarılmamıştır. Ölçeklerin güvenilirlik katsayılarının 0,70 ve üzeri çıkması ve birleşim ve ayrışım geçerlilik değerlerinin sırasıyla 0,70 ve üzeri ve 0,50 ve üzeri çıkması sonucu ise ölçeklerin güvenilirliğinin ve geçerliliğinin sağlandığı belirlenmiştir. Doğrulayıcı faktör analizi ile ölçeklerin güvenilirlik ve geçerliliğinin olduğu sonucuna varılması ve ölçek faktör yapılarının yapı geçerliliğinin sağlanması ortak yöntem yanlılığının olmadığının göstergesidir.

\section{Korelasyon analizi sonuçları}

Korelasyon analizinde araştırmada yer alan değişkenler arasındaki ilişkinin yönü ve gücü belirlenebilmektedir. Araştırma modelinde yer alan ölçek değişkenleri arasındaki ilişkinin ve ortak yöntem yanlılığının incelenmesi için korelasyon analizine yer verilmiştir. Korelasyon analizi sonucu elde edilen sonuçların değerlendirilmesinde, katsayının 0 ile \pm 0.30 arasında (düşük düzey ilişki), 0.31 ile \pm 0.70 arasında (orta düzey ilişki) ve son olarak 0.71 ile \pm 1.0 arasında (yüksek düzeyde ilişki) olması durumuna göre yorum yapılmaktadır (Çokluk, Şekercioğlu ve Büyüköztürk, 2012: 35). Araştırmada yer alan değişkenler arası korelasyon analizi ilişki katsayılarını gösteren sonuçlar Tablo 4'deki gibi elde edilmiştir.

Araştırma bulgularının daha anlaşılır şekilde ifade edilmesi amacıyla, algılanan tehdit, AT, algılanan duyarlılık, AD, algılanan ciddiyet, AC, kaygı, KY, dürtüsel satın alma ise DSA şeklinde kısaltılmıştır.

Tablo 4. Korelasyon Analizi Sonuçları

\begin{tabular}{|c|c|c|c|c|c|c|c|}
\hline & Ort. & Std. Sapma & AT & $\mathrm{AD}$ & AC & KY & DSA \\
\hline AT & 4,37 & 795 & 879 & & & & \\
\hline $\mathrm{AD}$ & 3,89 & 723 &, $490^{* *}$ & 861 & & & \\
\hline $\mathrm{AC}$ & 4,10 & 842 &, $636^{* *}$ &, $523^{* *}$ & 889 & & \\
\hline KY & 4,34 & 1,065 & $458^{* *}$ & $429^{* *}$ &, $592^{* *}$ & ,885 & \\
\hline DSA & 4,24 & 1,137 & $419^{*}$ & $338^{* *}$ &, $326^{*}$ &, $491^{* *}$ & ,897 \\
\hline
\end{tabular}

Araştırma modelindeki değişkenlerin birbirleri arasındaki ilişkileri ve her bir değişkenin ortalama düzeyini gösteren Tablo 5 incelendiğinde, katılımcıların algılanan tehdit (Ort:4,37; SS:0,795), algılanan ciddiyet (Ort:4,10; SS:0,842) düzeyleri ile kaygı düzeylerinin (Ort:4,34; SS:1,065) ve dürtüsel satın alma davranışlarının (Ort:4,24; SS:1,137) yüksek olduğu, algılanan duyarlılık (Ort:3,89; SS:0,723) düzeylerinin ise orta düzeyde oldukları söylenebilir. Bu sonuç araştırmanın gerçekleştirildiği zaman aralığında tüketicilerin COVID-19 algılanan tehdit düzeylerinin en fazla olduğu, algılanan duyarlılığın ise daha düşük düzeyde olduğunu göstermektedir.

Korelasyon değerleri incelendiğinde tüm ilişkilerin istatistiksel olarak anlamlı olduğu, algılanan tehdidin, algılanan duyarlılık, algılanan ciddiyet, kaygı ve dürtüsel satın alma ile orta düzeyde, pozitif yönde ilişkisi olduğu, algılanan duyarlılığın algılanan ciddiyet, kaygı düzeyi ve dürtüsel satın alma ile orta düzeyde ve pozitif yönde ilişkisi olduğu, algılanan ciddiyetin kaygı düzeyi ve dürtüsel satın alma ile orta düzeyde ve pozitif yönde ilişkisi olduğu, kaygı düzeyinin ise dürtüsel satın alma ile orta düzeyde ve pozitif yönde ilişkisi olduğu görülmektedir. Bu sonuç dürtüsel satın almanın en yüksek ilişkisinin kaygı düzeyinde gerçekleştiğini, en düşük ilişkinin ise algılanan ciddiyet düzeyinde gerçekleştiğini belirtmektedir. Kaygı düzeyinin en yüksek ilişkiye sahip olduğu değişken ise algılanan ciddiyet olarak tespit edilmiştir. Bu durum dürtüsel satın almanın en çok kaygı durumuyla birlikte arttı̆̆ını, kaygı düzeyinin ise en çok COVID-19'un algılanan ciddiyet düzeyinin artmasıyla arttığı şeklinde yorumlanabilir. Değişkenler arasında en yüksek düzey ilişki ise algılanan tehdit ve algılanan ciddiyet arasında elde edilmiştir.

Tablodaki korelasyon katsayıları arasında 0,90 ve üzeri ilişki katsayılarına rastlanmaması ortak yöntem yanlılığına neden olunmadığının bir göstergesidir. Diyagonal alanlarda yer alan AVE değeri kareköklerinin de değişkenler arası korelasyon katsayılarından yüksek çıkması, ayrışım geçerliliğinin sağlandığını göstermektedir (Hair, William, Bary ve Anderson, 2014). 
Etkileşim çerçevesinde oluşturulan değişkenler ve diğer araştırma değişkenleri arasındaki ilişkileri incelemeye yönelik gerçekleştirilen korelasyon analizi sonuçları ise Tablo 5'de gösterilmiştir. Etkileşim değişkenlerinin oluşturulması sürecinde standartlaştırılmış değerler kullanılmıştır. Öncelikle verilerin düzey değerlerinden aritmetik ortalamaları çıkarılmış, ardından elde edilen değer, standart sapmaya bölünmüş ve standartlaştırılmış etkileşim değerleri hesaplanmıştır (Yıldız, 2020: 74).

Tablo 5: Etkileşim Değişkenleri ve Diğer Değişkenler Arası Korelasyon Analizi Sonuçları

\begin{tabular}{|l|r|r|r|r|r|r|}
\hline & ATxAD & \multicolumn{1}{|c|}{ ATxAC } & DSAxAD & DSAxAC & \multicolumn{1}{c|}{ KYxAC } & \multicolumn{1}{c|}{ KYxAD } \\
\hline AT &, $829^{* *}$ &, $871^{* *}$ &, $359^{* *}$ &, $437^{* *}$ &, $546^{* *}$ &, $515^{* *}$ \\
AD &, $859^{* *}$ &, $564^{* *}$ &, $496^{* *}$ &, $470^{* *}$ &, $515^{* *}$ &, $720^{* *}$ \\
AC &, $658^{* *}$ &, $815^{* *}$ &, $391^{* *}$ &, $578^{* *}$ &, $792^{* *}$ &, $634^{* *}$ \\
KY &, $519^{* *}$ &, $592^{* *}$ &, $460^{* *}$ &, $537^{* *}$ &, $846^{* *}$ &, $823^{* *}$ \\
DSA &, $371^{* *}$ &, $330^{* *}$ &, $829^{* *}$ &, $807^{* *}$ &, $304^{* *}$ &, $343^{* *}$ \\
\hline
\end{tabular}

** $p 0.001$ düzeyinde anlaml

Tablo 5'de yer alan korelasyon katsayıları değerlendirildiğinde, tüm değerlerin istatistiksel olarak anlamlı olduğu ve pozitif yönlü ilişkilerin olduğu tespit edilmiştir. En yüksek ilişki, algılanan tehdit (AT) ve algılanan tehdit*algılanan ciddiyet (AT*AC) etkileşim değeri arasında yüksek düzeyde görülürken, en düşük ilişki, dürtüsel satın alma (DSA) ve kaygı*algılanan ciddiyet (KY*AC) etkileşim değeri arasında düzey düzeyde görülmüştür.

\section{Araştırma hipotezleri test sonuçları}

Bu analizlerin ardından, YEM'in son adımı olan yol analizi gerçekleştirilmiş ve bu sayede, öne sürülen hipotezler ışığında kurgulanan araştırma modeli test edilmiştir. Yol analizi bulgularının grafiksel gösterimi Şekil 2' de verilmiştir.

Düzenleyici rollerin araştırılmasında ise bağımsız değişken ve düzenleyici değişkenin çarpımından oluşturulan yeni bir değişken oluşturulmakta ve bu değişken etkileşim değişkeni olarak adlandırılmaktadır. Etkileşim teriminin bağımlı değişken üzerinde etkiye sahip olması sonucu düzenleyici rol ve etkiden bahsedilmektedir (Baron ve Kenny, 1986).

Yol analizi sonucunda uyum iyiliği değerlerine bakılarak önerilen modelin kabul edilip edilemeyeceği belirlenmektedir. Tablo 6 'da yer alan endeks değerlerine ve RMSEA, SRMR, $x^{2} / \mathrm{df}$ değerlerine bakıldığında, önerilen modelin kabul edilebilir uyum aralığında olduğu anlaşılmaktadır.

Tablo 6. Yapısal Model Uyum İyiliği Sonuçları

\begin{tabular}{llllll}
\hline Değişkenler & $X^{2} / \mathrm{df}$ & GFI & AGFI & CFI & RMSEA \\
\hline Araştırma Modeli & 2,67 & 0,95 & 0,93 & 0,97 & 0,06 \\
\hline Uyum iyiliği değerleri & $X^{2} / \mathrm{df}$ & GFI & AGFI & CFI & RMSEA \\
\hline İyi & $\leq 3$ & $\geq 0,90$ & $\geq 0,90$ & $\geq 0,97$ & $\leq 0,05$ \\
\hline Kabul edilebilir & $\leq 4-5$ & $0,89-0,85$ & $0,89-0,80$ & $\geq 0,95$ & $0,06-0,08$ \\
\hline
\end{tabular}

Kaynak: Jöreskog ve Sörbom, 1984, Meydan ve Şeşen, 2011.

Model uyumu yakalandıktan sonra, gizil değişkenler arasındaki tek yönlü nedensel ilişkilere bakılmış ve hangi hipotezlerin kabul/ret edildiği belirlenmiştir. Analiz sonuçları Tablo 7'de verilmiştir. 


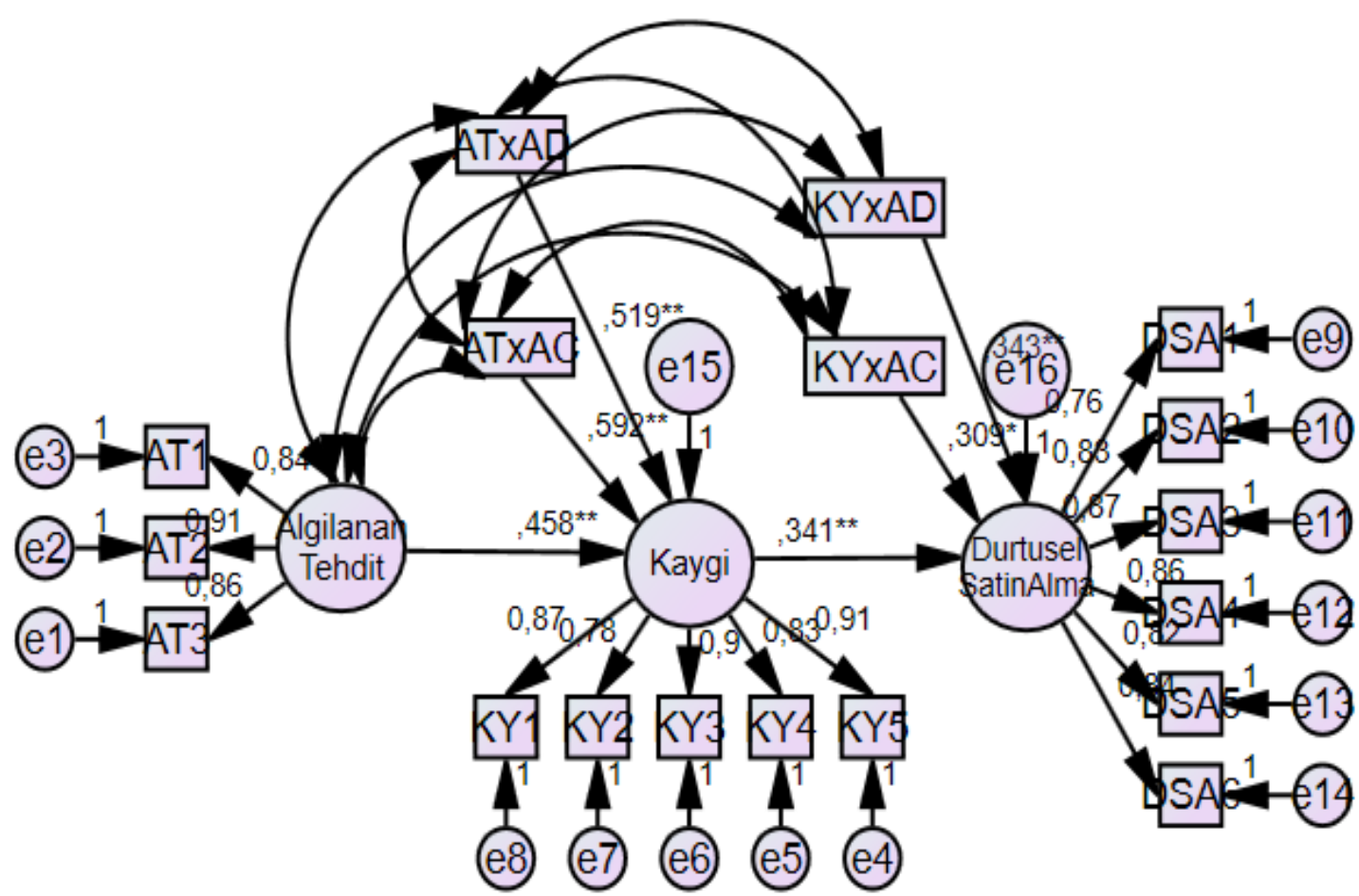

Şekil 2. Araştırma Modeli Yapısal Eşitlik Yol Analizi Sonuçları

Tablo 7. Araştırma Modeli Hipotez Test Sonuçları

\begin{tabular}{|l|c|c|c|c|}
\hline & Beta & Std.Hata & $\mathrm{t}$ & $\mathrm{p}$ \\
\hline H1:Algılanan Tehdit->Kayg1 & $0,458^{* *}$ & 0,059 & 10,306 & 0,000 \\
\hline H2: Kayg1->Dürtüsel Satın Alma & $0,341^{* *}$ & 0,050 & 7,267 & 0,000 \\
\hline H3: Alg1lanan TehditXAlg1lanan Duyarlılık->Kayg1 & $0,519^{* *}$ & 0,008 & 14,703 & 0,000 \\
\hline H4: KaygıXAlgılanan Duyarlılık->Dürtüsel Satın Alma & $0,343^{* *}$ & 0,009 & 7,302 & 0,000 \\
\hline H5: Algılanan TehditXAlg1lanan Ciddiyet->Kayg1 & $0,592^{* *}$ & 0,009 & 12,148 & 0,000 \\
\hline H6: Kayg1XAlgılanan Ciddiyet->Dürtüsel Satın Alma & $0,309^{* *}$ & 0,008 & 6,393 & 0,000 \\
\hline${ }^{* *} p=0,001$ de anlamlı & & & &
\end{tabular}

Hipotez test sonuçlarının incelenmesine yönelik oluşturulan yapısal eşitlik yol analizi sonuçlarını gösteren Tablo 7 incelendiğinde, tüm etki değerlerinin $\mathrm{p}=0,001$ önem düzeyinde anlamlı kabul edildiği görülmektedir. Etki dereceleri incelendiğinde algılanan tehdidin kaygı üzerinde $(\beta=0.458, p<0.01)$ $\% 45,8$, kaygının dürtüsel satın alma üzerinde $(\beta=0.341, \mathrm{p}<0.01) \% 34,1$ oranında etkisi olduğu belirlenmiş ve $\mathrm{H} 1$ ve $\mathrm{H} 2$ hipotezleri kabul edilmiştir. Moderatör etkiler incelendiğinde algılanan tehdidin kayg1 üzerindeki etkisinde algılanan duyarlılı̆ın $(\beta=0.519, \mathrm{p}<0.01) \% 51,9$, algılanan ciddiyetin $(\beta=0.592, \mathrm{p}<0.01) \% 59,2$ oranında etkisi olduğu saptanmıştır. H3 ve H5 hipotezi kabul edilmiştir. Kaygı düzeyinin dürtüsel satın alma üzerindeki etkisinde algılanan duyarlılı̆ın $(\beta=0.343$, $\mathrm{p}<0.01) \% 34,3$, algılanan ciddiyetin $(\beta=0.309, \mathrm{p}<0.01) \% 30,9$ oranında etkisi olduğu tespit edilmiştir. H4 ve H6 hipotezi kabul edilmiştir.

\section{Sonuç, tartışma ve öneriler}

COVID-19 salgını, küresel ölçekte bireyler arasında korku, panik ve belirsizliği tetikleyerek tüketici davranışlarında gözle görülür değişikliklere neden olmuştur. Belirsizlik dönemlerinde hastalığın algılanan tehdidin bireyler üzerinde kaygı yaratması dürtüsel satın alma davranışının artmasına sebep olmuştur.

Mevcut çalışmada Uyaran-Organizma-Tepki (S-O-R) paradigması ve Sağlı İnanç Modeli çerçevesinde, COVID-19 döneminde algılanan tehdit ve algılanan kaygının tüketicilerin dürtüsel satın almaları üzerindeki etkisi ve bu etkileşimde algılanan duyarlılık ve algılanan ciddiyetin düzenleyici rollerinin ortaya çıkarılması amaçlanmıştır. Araştırma sonucunda tüketicilerin COVID-19'a karşı algıladıkları tehdit artarsa kaygı düzeylerinin artacağı, benzer şekilde kaygı düzeyleri artarsa dürtüsel satın alma davranışlarının artacağı saptanmıştır. Tüketicilerin COVID-19'a karşı algılanan duyarlılık ve ciddiyet seviyelerinin artırılması bu etkileri güçlendirecektir. Çalışmadan elde edilen bulgulara göre algılanan 
tehdidin kaygı üzerindeki etkisinde algılanan ciddiyetin düzenleyici etkisinin daha fazla olduğu, kaygı düzeyinin dürtüsel satın alma üzerindeki etkisinde ise algılanan duyarlılığın düzenleyici etkisinin daha fazla olduğu belirlenmiştir. Tüketicilerin algılanan COVID-19 tehdidinin artması kaygı düzeylerini artıracak, kaygı düzeylerinin artması da dürtüsel satın almayı artıracaktır. Algılanan tehdidin kaygı üzerindeki etkisinde algılanan duyarlılığın ve ciddiyetin düzenleyici role sahip olması, tüketicilerin COVID-19 duyarlılı̆̆ının ve ciddiyetinin bu etkiyi güçlendirdiğini, algılanan duyarlılığın ve ciddiyetin artması durumunda algılanan COVID-19 tehdidinin kaygı üzerindeki etkisinin güçleneceği saptanmıştır. Moderatör etkilere göre bu etkileşimlerde algılanan ciddiyetin güçlendirici etki derecesinin daha fazla olduğu ortaya çıkmıştır. COVID-19 kaygı düzeyinin dürtüsel satın alma üzerindeki etkisinde algılanan duyarlılı̆̆ın ve ciddiyetin düzenleyici role sahip olduğu sonucuna ulaşılırken, algılanan duyarlılığın artmasının bu etkiyi artıracağı, ciddiyetin ise azaltacağı sonucuna ulaşılmıştır. Bu sonuç kaygı düzeyinin dürtüsel satın almayı artırdığı durumlarda, tüketicilerin duyarlılığının da artmasının bu etkiyi artıracağı şeklinde yorumlanır. Algılanan ciddiyetin artması durumunda ise kaygı düzeyinin dürtüsel satın alma üzerindeki etkisi azalma yönünde eğilim gösterecektir.

Çalışmadan elde edilen bulgular literatürdeki çalışma sonuçlarıyla karşılaştırıldığında, algılanan tehdidin kaygı üzerindeki etkisi Song, Yao ve Wen (2021), Shahzad vd. (2020), Paredes vd. (2021) ve Zheng vd. (2020)'in çalışmalarıyla benzerlik göstermektedir. COVID-19 nedeniyle ortaya çıkan kaygının, dürtüsel satın alma üzerindeki etkisi Fast vd. (2015), Laato vd. (2020), Pandita, Mishra ve Chib (2021) ve Xiao, Zhang ve Zhang (2020)'in çalışmalarıyla, düzenleyici etkiler ise Sheeran ve Abraham (1996), Joshi ve Rahman (2015), Laato vd. (2020)'nun çalışmalarıyla paralellik göstermektedir.

$\mathrm{Bu}$ sonuçlar ışığında şirketlerin COVID-19 döneminde tüketici davranışlarında meydana gelen değişiklikleri iyi analiz etmeleri ve bu doğrultuda yeni stratejiler üretmeleri gerektiği ifade edilebilir.

İleride yapılacak çalışmalarda COVID-19 algılanan tehdit, kaygı, duyarlılık ve ciddiyet değişkenlerinin stoklama ve israf önleme davranışları üzerindeki etkisi ele alınabilir. Ayrıca farklı araştırma modelleri ve veri toplama yöntemleri ile araştırmalar derinleştirilebilir. COVID-19 pozitif ve negatif vakalar üzerinde karşılaştırmalı analiz yapılabilir. COVID-19 kısıtlamalarından çok etkilenen 20 yaş altı ve 65 yaş üstü tüketiciler üzerinde başka bir araştırma yapılabilir. Bu süreçte acil ihtiyaç niteliğinde görülen tuvalet kâğıdı, kolonya, dezenfektan vb. hijyen ürünleri satın alma, stoklama davranışları özelinde araştırmalar gerçekleştirilebilir.

Araştırma sonuçlarının pazarlama yöneticileri için yol gösterici olacağı düşünülmektedir. Yöneticilerin COVID-19 döneminde vaka ve vefat sayısındaki artış ve azalışa göre tüketici davranışının nasıl değişeceğini değerlendirmeleri gerektiği sonucuna varılabilir. Dönemsel olarak değerlendirildiğinde vaka sayılarındaki artış durumunda algılanan tehdit durumunun artması kaygı durumunu artıracak, artan kaygı durumu da tüketicileri daha fazla dürtüsel satın almaya yöneltir şeklinde çıkarıma varılabilir. Aynı süreçte tüketicilerin algılanan duyarlılığının artması ve durumun ciddiyetini daha fazla anlaması, kaygı düzeyinin artmasına olumlu yönde etki edecektir. Artan kaygı durumunun tüketicileri dürtüsel satın almaya daha fazla yönelttiği durumlarda ise tüketicilerin duyarlılığının artması bu etkiyi artırırken, ciddiyetin artması kaygının dürtüsel satın alma üzerindeki etkisini azaltacaktır çıkarımına ulaşılabilir. Vaka ve vefat sayısına göre tüketicilerde oluşacak ciddiyet, kaygı düzeyinin dürtüsel satın almaya etkisini azaltma yönünde katkı sağlayacaktır. Bu tür dönemlerde pazarlama yöneticilerinin pazarlama stratejilerini ve faaliyetlerini bu anlamda yönetmesi gerektiği ifade edilebilir.

Çalışma, COVID-19 testi negatif olan ve testi olmayan kişiler üzerinde yapılımıştır. Bu, çalışmanın bir sınırlamasıdır. Çalışmadan elde edilen veriler 4 Ocak-15 Ocak 2021 tarihleri arasında toplanmıştır. Sonuçlar genel olarak değil bu tarih aralığında vaka durumuna göre yorumlanmalıdır. Bu nedenle, daha geniş bir örneklem grubu ile elde edilen bulgular araştırılabilir. Ayrıca örneklem grubunda kendileri negatif olan katılımcıların çevrelerinde COVID-19 testi pozitif kişiler olup olmadığı da göz ardı edilmiştir. Kişinin testi pozitif olmasa bile ailesinden veya arkadaşlarından birinin COVID-19 pozitif çıkması bu kişilerin tüketim davranışlarını etkileyecektir. İleride bu durumları daha iyi tanımlamak için bu tür sorular dikkate alınarak çalışmalar tekrar edilebilir.

\section{Hakem Değerlendirmesi / Peer-review:}

Dış bağımsız

Externally peer-reviewed 


\section{Çıkar Çatışması / Conflict of interests:}

Yazar(lar) çıkar çatışması bildirmemiştir.

The author(s) has (have) no conflict of interest to declare.

\section{Finansal Destek / Grant Support:}

Yazar bu çalışma için finansal destek almadığını beyan etmiştir.

The author declared that this study has received no financial support.

\section{Etik Kurul Onayı/ Ethics Committee Approval:}

Bu çalışma için etik kurul onayı, İstanbul Ticaret Üniversitesi, Etik Kurulu/Komitesinden 25/12/2020 tarihli E-65836846-044-202499 sayılı karar ile alınmıştır.

Ethics committee approval was received for this study from Istanbul Commerce University, Ethics Committee on 25/12/2020 and E-65836846-044-202499 document number.

\section{Yazar Katkıları / Author Contributions:}

Fikir/Kavram/Tasarım - Idea/Concept/Design: M.S., B.T. Veri Toplama ve/veya İşleme - Data Collection and/or Processing: M.S., B.T. Analiz ve/veya Yorum - Analysis and/or Interpretation: M.S., B.T. Kaynak Taraması - Literature Review: M.S., B.T. Makalenin Yazımı - Writing the Article: M.S., B.T. Eleştirel İnceleme - Critical Review: M.S., B.T. Onay - Approval: M.S., B.T.

\section{Kaynakça / References}

American Psychological Association: https://dictionary.apa.org/anxiety adresinden alındı

Addo, P. C., Jiaming, F., Kulbo, N. B., \& Liangqiang, L. (2020). COVID-19: fear appeal favoring purchase behavior towards personal protective equipment. The Service Industries Journal, 40(7-8), 471-490.

Altunışık, R., Coşkun, R., Bayraktaroğlu, S., Yıldırım, E., (2012). Sosyal Bilimlerde Araştırma Yöntemleri. (7.Baskı). Adapazarı: Sakarya Yayıncılık.

Bagozzi, R. P. (1986). Principles of marketing management. Science Research Associates.

Beck, A. T., \& Clark, D. A. (1997). An information processing model of anxiety: Automatic and strategic processes. Behaviour research and therapy, 35(1), 49-58.

Baron, R. M., ve Kenny, D. A., (1986). “The Moderator-Mediator Variable Distinction in Social Psychological Research: Conceptual, Strategic, and Statistical Considerations", Journal of Personality and Social Psychology, 51(6).

Becker, M. H., \& Maiman, L. A. (1980). Strategies for enhancing patient compliance. Journal of community health, 113-135.

Bellini, S., Cardinali, M. G., \& Grandi, B. (2017). A structural equation model of impulse buying behaviour in grocery retailing. Journal of Retailing and Consumer Services, 36, 164-171.

Bergeron, S. L., \& Sanchez, A. L. (2005). Media effects on students during SARS outbreak. Emerging infectious diseases, 11(5), 732-734.

Bish, A., \& Michie, S. (2010). Demographic and attitudinal determinants of protective behaviours during a pandemic: A review. British journal of health psychology, 15(4), 797-824. 
Bults, M., Beaujean, D. J., Richardus, J. H., \& Voeten, H. A. (2015). Perceptions and behavioral responses of the general public during the 2009 influenza A (H1N1) pandemic: a systematic review. Disaster medicine and public health preparedness, 9(2), 207-219.

Butler, G., \& Mathews, A. (1987). Anticipatory anxiety and risk perception. Cognitive therapy and research, 11(5), 551-565.

Cao, W., Fang, Z., Hou, G., Han, M., \& Xu, X. (2020). The psychological impact of the COVID-19 epidemic on college students in China. Psychiatry research, 287.

Carico , R. R., Sheppard, J., \& Thomas, C. B. (2021). Community pharmacists and communication in the time of COVID-19: Applying the health belief model. Research in Social and Administrative Pharmacy, 17, 1984-1987.

Champion, V. L. (1984). Instrument development for health belief model constructs. Advances in nursing science, 6(3), 73-85.

Champion, V. L., \& Skinner, C. S. (2008). The health belief model. Health behavior and health education: Theory, research, and practice, 4, 45-65.

Chin, W.W.,Gopal, A., Salisbury, W.D., (1997). "Advancing the Theory of Adaptive Struc turation: The Development of a Scale to Measure Faithfulness of Appropriation", Information Systems Research, $8(4), 342-367$.

COVID-19 Insights: Consumer Behavior. (2021, Şubat 10). Ipsos: https://www.ipsos.com/endk/COVID-19-insights-consumer-behaviour (2021, Mart 16).

Çokluk, Ö. S., Şekercioğlu, G. ve Büyüköztürk, S. (2012), “Multivariate statistics for social sciences SPSS and Lisrel applications", Ankara: Pegem Academi

D'Antoni, J. S., \& Shenson, H. L. (1973). Impulse Buying Revisited-Behavioral Typology. Journal of Retailing, 49(1).

De Pietri , S., \& Chiorri, C. (2021). Early impact of COVID-19 quarantine on the perceived change of anxiety symptoms in a non-clinical, non-infected Italian sample Effect of COVID-19 quarantine on anxiety. Journal of affective disorders reports, 4 .

Dittmar, H. (2005). “Compulsive Buying - A Growing Concern? An Examination of Gender, Age, and Endorsement of Materialistic Values as Predictors. British Journal of Psychology, 96, 467-491.

Donovan, R., \& Rossiter, J. (1982). Store atmosphere: an environmental psychology approach. Journal of retailing, 58(1), 34-57.

Donthu, N., \& Gustafsson, A. (2020). Effects of COVID-19 on business and research. Journal of Business Research, 117, 284-289.

Duan, L., \& Zhu, G. (2020). Psychological interventions for people affected by the COVID-19 epidemic. The Lancet Psychiatry, 7(4), 300-302.

Farooq, A., Laato, S., \& Islam, A. N. (2020). Impact of online information on self-isolation intention during the COVID-19 pandemic: cross-sectional study. Journal of medical Internet research, 22(5), 115.

Fast, S. M., González, M. C., Wilson, J. M., \& Markuzon, N. (2015). Modelling the propagation of social response during a disease outbreak. Journal of The Royal Society Interface, 12(104), 20141105.

Ferguson, N. (2007). Capturing human behaviour. Nature, 446(7137), 733-733.

Fiske, D.W. (1982). Convergent-discriminant validation in measurements and Research strategies, D. Brinberg ve L. Kidder (Eds.), New directions for methodology of social and behavioral science: Forms of validity in Research. San Francisco: Jossey-Bass.

Fornell, C., ve Larcker F. D., (1981). "Evaluating Structural Equation Models with Unobservable Variables and Measurement Error", Journal of Marketing Research,18, 39-50.

Fu , S., Chen , X., \& Zheng , H. (2020). Exploring an adverse impact of smartphone overuse on academic performance via health issues: a stimulus-organism-response perspective. Behaviour \& Information Technology, 1-13.

Goodwin, R., Haque, S., Neto , F., \& Myers , L. B. (2009). Initial psychological responses to Influenza A, H1N1 ("Swine flu"). BMC Infectious Diseases, 9(1), 1-6. 
Hair J. F. J., Black C.W., Babin J.B., Anderson, E.R., and Tatham, L. R. (2006). Multivariate Data Analysis. Upper Saddle River, N.J: Prentice Hall Inc.

Hair, J. F., William C. B., Bary J. B., \& Anderson, R. E. (2014). Multivariate Data Analysis, Seventh Edition, Upper Saddle River, New Jersey: Prentice Hall.

Hawryluck, L., Gold, W. L., Robinson, S., Pogorski, S., Galea, S., \& Styra, R. (2004). SARS control and psychological effects of quarantine, Toronto, Canada. Emerging infectious diseases, 10(7).

Hayden, J. A. (2009). Health belief model. introduction to health behavior theory. Canada: Jones and Barlett Publishers.

Honigsbaum, M. (2013). A history of the great influenza pandemics: death, panic and hysteria, 18301920 (Vol. 30). IB Tauris.

Islam, T., Sheikh, Z., Hameed, Z., \& Khan, I. U. (2018). Social comparison, materialism, and compulsive buying based on stimulus-response-model: a comparative study among adolescents and young adults. Young Consumers, 19, 19-37.

Jeong, H., Yim, H. W., Song, Y.-J., Ki, M., Min, J.-A., Cho, J., \& Chae, J.-H. (2016). Mental health status of people isolated due to Middle East Respiratory Syndrome. Epidemiology and health, 38.

Joshi , Y., \& Rahman, Z. (2015). Factors affecting green purchase behaviour and future research directions. International Strategic management review, 3(1-2), 128-143.

Jöreskog, K. G., ve Sörbom, D., (1984). Lisrel VI. “Analysis of Linear Structural Relationships by Maximum Likelihood, Instrumental Variables, and Least Squares Methods", Mooresville, Indiana: Scientific Software.

Kim, S.-W., \& Su, K.-P. (2020). Using psychoneuroimmunity against COVID-19. Brain, behavior, and immunity, 87, 4-5.

Laato, S., Islam, A. N., Farooq, A., \& Dhir, A. (2020). Unusual purchasing behavior during the early stages of the COVID-19 pandemic: The stimulus-organism-response approach. Journal of Retailing and Consumer, 57.

Lin, T. T., \& Bautista, J. R. (2016). Predicting intention to take protective measures during haze: The roles of efficacy, threat, media trust, and affective attitude. Journal of health communication, 21(7), 790799.

Ling, M., Kothe, E. J., \& Mullan, B. A. (2019). Predicting intention to receive a seasonal influenza vaccination using Protection Motivation Theory. Social Science \& Medicine, 233, 87-92.

Liu, H., Chu, H., Huang, Q., \& Chen, X. (2016). Enhancing the flow experience of consumers in China through interpersonal interaction in social commerce. Computers in Human Behavior, 58, 306-314.

Marteau, T. M., \& Bekker, H. (1992). The development of a six-item short-form of the state scale of the Spielberger State - Trait Anxiety Inventory (STAI). British journal of clinical Psychology, 31(1), 301306.

Mehrabian, A., \& Russell, J. A. (1974). An approach to environmental psychology. Cambridge: MIT Press.

Meydan, C. H., ve Şeşen, H., (2011). Structural Equation Modeling AMOS Applications, Ankara: Detay Yayıncilik

Mohan, G., Sivakumaran, B., \& Sharma, P. (2013). Impact of store environment on impulse buying behavior. European Journal of marketing.

Mooi. E., and Sarstedt, M. (2011). A concise guide to market research: The process, data, and methods using IBM SPSS Statistics. New York: Springer.

Müller, A., Mitchell, J. E., Crosby, R. D., Cao, L., Johnson, J., Claes, L., \& Zwaan, M. (2012). Mood states preceding and following compulsive buying episodes: An ecological momentary assessment study. Psychiatry Research, 200(2-3), 575-580.

Naeem, M. (2021). Understanding the customer psychology of impulse buying during COVID-19 pandemic: implications for retailers. International Journal of Retail \& Distribution Management, 49(3), 377-393. 
Netemeyer, R.,G. Bearden, W. O., ve Sharma, S., (2003). "Scaling Procedures: Issues and Applications". Thousand Oaks, CA: Sage Publication.

Özyılmaz, A., ve Eser. S. (2013). Ortak Metod Varyansı Nedir? Nasıl Kontrol Edilebilir?, 21.Ulusal Yönetim ve Organizasyon Kongresi Bildiriler Kitabı, Kütahya Dumlupınar Üniversitesi. 1. Basım. Nobel Akademik Yayıncılık, 500-508.

Pandita, S., Mishra, H. G., \& Chib, S. (2021). Psychological impact of COVID-19 crises on students through the lens of Stimulus-Organism-Response (SOR) model. Children and Youth Services Review, 120, 105783.

Paredes, M. R., Apaolaza, V., Fernandez-Robin, C., Hartmann, P., \& Yañez-Martinez, D. (2021). The impact of the COVID-19 pandemic on subjective mental well-being: The interplay of perceived threat, future anxiety and resilience. Personality and Individual Difference, 170.

Peck, J., \& Childers, T. L. (2006). If I touch it I have to have it: Individual and environmental influences on impulse purchasing. Journal of business research, 59(6), 765-769.

Peng, C., \& Kim, Y. G. (2014). Application of the stimuli-organism-response (SOR) framework to online shopping behavior. Journal of Internet Commerce, 13(3-4), 159-176.

Podsakoff, P.M., MacKenzie, S.B., and Podsakoff, N.P. (2012). Sources of method bias in social science research and recommendations on how to control it, Annual Review of Psychology, 63, 539-569. https://doi.org/10.1146/annurev-psych-120710-100452

Prakash, A., \& Sharma, A. (2016). Dimensions of Point of Purchase Factors in Impulsive Buying of Women's Skincare Cosmetics in India. Journal of Business and Retail Management Research, 10(2), $30-43$.

Retail customer experience. (2020, Mart 15). COVID-19 spurring impulse spending, reveals survey: https://www.retailcustomerexperience.com/news/COVID-19-spurring-impulse-spendingreveals-survey/ adresinden alındı

Richardson, H.A., Simmering, M.J., \& Sturman, M.C. (2009). A tale of three perspectives: Examining post hoc statistical techniques for detection and correction of common method variance, Organizational Research Methods, 12, 762-800. https://doi.org/10.1177/1094428109332834.

Rogers, R. W. (1975). A protection motivation theory of fear appeals and attitude change1. The journal of psychology, 91(1), 93-114.

Rohleder, P. (2012). Critical issues in clinical and health psychology. London: SAGE Publications.

Rook , D. W., \& Hoch, S. J. (1985). Consuming Impulse. Journal of Advances in Consumer Research, 12(1), 23-27.

Rook, D. W. (1987). The buying impulse. Journal of consumer research, 14(2), 189-199.

Rubin, G. J., Amlot, R., Page, L., \& Wessely, S. (2009). Public perceptions, anxiety, and behaviour change in relation to the swine flu outbreak: cross sectional telephone survey. Bmj, 1-8.

Ruthig, J. C. (2016). Health risk perceptions and exercise in older adulthood: an application of protection motivation theory. Journal of Applied Gerontology, 35(9), 939-959.

Šeinauskienė, B., Maščinskienė, J., \& Jucaitytè, I. (2015). The relationship of happiness, impulse buying and brand loyalty. Procedia-Social and Behavioral Sciences, 213, 687-693.

Shahzad, F., Du, J., Khan, I., Fateh, A., Shahbaz, M., Abbas, A., \& Wattoo , M. U. (2020). Perceived Threat of COVID-19 Contagion and Frontline Paramedics' Agonistic Behaviour: Employing a Stressor-Strain-Outcome Perspective. Journal of Environmental Research and Public Health, 17(14).

Shaikh, A. (2020). Effective factors in changing the buying behavior of consumer due to COVID-19. Studies in Indian Place Names, 40(68), 408-414.

Shao, T. A. (2002). Marketing Research: An aid to Decision Making. SouthWestern/Thomson Learning.

Sheeran, P., \& Abraham, C. (1996). The health belief model. P. Sheeran, C. Abraham, M. Conner, \& P. Norman (Dü) içinde, Predicting health behaviour: Research and practice with social cognition models (s. 23-61). Open University Press.

Sheth, J. (2020). Impact of COVID-19 on consumer behaviour: will the old habits return or die. Journal of Business Research, 117, 280-283. 
Skinner, B. F. (1935). The generic nature of the concepts of stimulus and response. The Journal of General Psychology, 12(1), 40-65.

Slama, M. E., \& Tashchian, A. (1987). Validating the SOR paradigm for consumer involvement with a convenience good. Journal of the Academy of Marketing Science, 15(1), 36-45.

SlickDeals. (2020). Americans increased impulse spending by 18\% during the COVID - 19 pandemic. Mart 20, 2021 tarihinde https://www. prnewswire.com/news-releases/americans-increasedimpulse-spending-by-18-percent-during-the-COVID-19-pandemic-according-to-new-surveycommissioned-by-slickdeals-301055530.html adresinden alındı

Slovic, P., Fischhoff, B., \& Lichtenstein, S. (1982). Why study risk perception? Risk analysis, 2(2), 83-93.

Sofi, S. A., \& Nika, F. A. (2017). Role of Intrinsic Factors in Impulsive Buying Decision: An Empirical Study of Young Consumers. Arab Economic and Business Journal, 1(2), 29-43.

Song , S., Yao, X., \& Wen, N. (2021). What motivates Chinese consumers to avoid information about the COVID-19 pandemic?: The perspective of the stimulus-organism-response model. Information Processing \& Management, 58(1).

Spence, K. W. (1950). Cognitive versus stimulus-response theories of learning. Psychological Review, 57(3), 159-172.

Sreelakshmi, C. C., \& Prathap, S. K. (2020). Continuance adoption of mobile-based payments in COVID19 context: an integrated framework of health belief model and expectation confirmation model. International Journal of Pervasive Computing and Communications, 16(4), 351-369.

Tehseen, S., Ramayah, T., and Sajilan, S. (2017). Testing and Controlling for Common Method Variance: A Review of Available Methods, Journal of Management Sciences, 4(2), 146-175. https://doi.org/10.20547/jms.2014.1704202

Valence, G., d'Astous, A., \& Fortier, L. (1988). Compulsive buying: Concept and measurement. Journal of consumer policy, 11(4), 419-433.

Verhagen, T., \& Van Dolen, W. (2011). The influence of online store beliefs on consumer online impulse buying: A model and empirical application. Information \& Management, 48(8), 320-327.

Verplanken, B., Herabadi, A. G., Perry, J. A., \& Silvera, D. H. (2005). Consumer style and health: The role of impulsive buying in unhealthy eating. Psychology \& Health, 20(4), 429-441.

Wang , C., Pan , R., Wan, X., Tan, Y., Xu, L., Ho, C. S., \& Ho, R. C. (2020). Immediate psychological responses and associated factors during the initial stage of the 2019 coronavirus disease (COVID-19) epidemic among the general population in China. International journal of environmental research and public health, 17(5), 1-25.

Wheaton, M. G., Berman, N. C., Franklin, J. C., \& Abramowitz, J. S. (2010). Health anxiety: Latent structure and associations with anxiety-related psychological processes in a student sample. Journal of Psychopathology and Behavioral Assessment, 32(4), 565-574.

Xiao , H., Zhang, Z., \& Zhang, L. (2020). A diary study of impulsive buying during the COVID-19 pandemic. Current Psychology, 1-13.

Yang, Z. J. (2012). Too Scared or Too Capable? Why Do College Students Stay Away from the H1N1 Vaccine? Risk Analysis: An International Journal, 32(10), 1703-1716.

Yazıcıŏlu, Y. ve Erdoğan, S. (2004). SPSS Uygulamalı Bilimsel Araştırma Yöntemleri. Detay Yayıncılık, Ankara.

Yıldız, U., (2020). Çoklu Doğrusal Regresyon Modelinin Uzantıları, Edt. Timurler, M.S. Ekonominin Temelleri, Anadolu Üniversitesi Açıöğretim Fakültesi Yayınları. Eskişerhir.

Yuen, K. F., Wang, X., Ma, F., \& Li, K. X. (2020). The psychological causes of panic buying following a health crisis. International journal of environmental research and public health, 17(10), 3513.

Zhang, H., Lub, Y., Gupta, S., \& Zhao, L. (2014). What motivates customers to participate in social commerce? The impact of technological environments and virtual customer experiences. Information \& Management, 51(8), 1017-1030.

Zhao, X., \& Cai, X. (2009). The role of risk, efficacy, and anxiety in smokers' cancer information seeking. Health Communication, 24(3), 259-269. 
Zheng, L., Lippke, S., Chen, Y., Li, D., \& Gan, Y. (2019). Future orientation buffers depression in daily and specific stress. PsyCh journal, 8(3), 342-352.

Zheng, L., Miao, M., Lim, J., Li, M., Nie, S., \& Zhang, X. (2020). Is lockdown bad for social anxiety in COVID-19 regions?: a national study in the SOR perspective. International Journal of Environmental Research and Public Health, 17(12), 4561.

https://covid19.saglik.gov.tr/TR-66935/genel-koronavirus-tablosu.html 